\title{
Enhancing Ecologically Sustainable Management of Deadwood in Kenya's Natural Forests
}

\author{
Sylvester Ngome Chisika (iD) and Chunho Yeom \\ International School of Urban Sciences, University of Seoul, 02504 Seoul, Republic of Korea \\ Correspondence should be addressed to Chunho Yeom; chunhoy7@uos.ac.kr
}

Received 23 November 2020; Revised 12 February 2021; Accepted 22 February 2021; Published 5 March 2021

Academic Editor: Ahmad A. Omar

Copyright (C) 2021 Sylvester Ngome Chisika and Chunho Yeom. This is an open access article distributed under the Creative Commons Attribution License, which permits unrestricted use, distribution, and reproduction in any medium, provided the original work is properly cited.

\begin{abstract}
The need for ecologically sustainable management of natural forests has assumed greater prominence in conservation and climate change discourses. However, the identification of deadwood, a critical component of natural forests, continues to receive little attention around the world. Through a review of the existing literature, this study sought to promote consciousness and awareness on the value of deadwood using the case of Kenya's natural forests in the wider context of biodiversity conservation and climate change. Results substantiate that deadwood in natural forests performs a vital function in forest biological and ecological functions. However, forest degradation through the removal of deadwood, even though widely neglected, results in considerable biodiversity loss and might alter natural forest ecosystems, thereby exacerbating the impacts of climate change. In Kenya, despite the recent sophistication of forest management tools, including the development of the Draft Forest Policy, 2020, and enactment of the Forest Conservation and Management Act, 2016, to increasingly recognize the more progressive forest management paradigms such as participatory forest management in natural forest management, the current deadwood management practice is faulty and could yield outcomes contrary to the policy intentions and the wider provisions of ecologically sustainable forest management. It is because major policy documents lack robust and explicit guidelines on achieving ecologically sustainable management of deadwood despite its centrality in providing ecosystem services and as a highly dependable source of energy resources for over $70 \%$ of the Kenyan population. Moreover, deadwood management appears to be affected by many complex biological, technical, policy, and socioeconomic factors that appear to be acting together against sustainable deadwood management. Still, perhaps most importantly, the absence of research on the topic is the most outstanding challenge. Therefore, in the future, improving the sustainable management of natural forests will require the restoration of deadwood and increasing consciousness on the value of deadwood through more research studies.
\end{abstract}

\section{Introduction}

Globally, natural forests provide many ecosystem services needed for biodiversity conservation and sustainable management $[1,2]$. Millions of people depend on forests for livelihood. Hence, there is the need to direct policies toward improving forest management in order to promote ecologically sustainable management where ecological processes are maintained, biodiversity is preserved, and a full range of benefits accrue to the society within the natural limits of a given natural forest $[3,4]$.

However, in the wake of climate change concerns acting together with the growing human population accompanied by the seemingly unsustainable production and consumption patterns, especially related to wood energy resources and other existential threats, deforestation threatens the capacity of natural forests to generate benefits to the society in line with the ecologically sustainable forest management paradigm. Studies document that the destruction and deforestation of natural forest ecosystems start when huntergatherer communities shift to agricultural systems [5]. While discourses on deforestation have gained recognition in this era of climate change, the plunder and degradation of natural forests, due to legally sanctioned removal of deadwood, goes unnoticed by the society and generally remains an understudied subject area around the globe $[4,6-13]$. 
Deadwood is a general term defining dead or dying trees fallen on the ground in forests [14]. Deadwood may also include carbon pools found in forests [9] or stumps, heartwood, branches, twigs, or barks on the ground and in the canopy of living trees or stag-headed trees $[15,16]$. These dead or dying trees create high-diversity deadwood and are associated with numerous microhabitats for diverse life forms $[4,5,9,10]$. It is with backdrop that many countries around the world have formulated robust policies to raise public consciousness on the need to sustainably conserve and manage deadwood resources.

On the contrary, in Kenya, information on deadwood as a critical component of natural forests remains scanty. However, with the growing human population accompanied by the rising demand for forest products, especially wood energy resources, this scarcity of information on deadwood represents a major dilemma for the sustainable management of natural forests in the country for two reasons. Firstly, public awareness on the importance of deadwood is low. Secondly, in the wake of climate change and other existential threats, there is limited awareness on the strategies and policies that could be employed in order to promote successful natural forest regeneration and sustainable management of deadwood resources. Consequently, this paper seeks to address the above challenges by reviewing the current status of deadwood management in Kenya's gazetted natural forests in order to raise awareness on the importance of deadwood and suggest how ecologically sustainable forest management could be achieved by incorporating deadwood management policies and strategies such as bioeconomy. Unlike previous studies which have examined the topic of deadwood from the strict perspective of sustainable forest management, for the first time, this paper will first explore the global literature on the concept of ecologically sustainable forest management in the context of the bioeconomy of deadwood and then apply the findings to Kenya's context in order to draw the policy implications of this paper.

Kenya has been chosen to represent the African continent in this study because the country is regarded as a low forest cover country compared to the recommended constitutional requirement of $10 \%$ and the minimum forest cover per country recommended by the United Nations [17]. The country has $7.4 \%$ of forest cover with diverse ecosystems [17]. These forests are highly regarded as important natural capital providing many ecosystem services in the quest for sustainable development. Forestry provides up to $3.6 \%$ of Kenya's gross domestic product (GDP) $[17,18]$. In addition, the sector's indirect and induced effects in other associated sectors range between 33 and 39\% of the country's GDP $[17,18]$. Forests also provide a variety of goods, which directly support the subsistence livelihoods of many communities. For instance, biomass constitutes approximately $80 \%$ of all energy utilized in Kenya [18]. This energy demand is bound to rise exponentially with the growing population and urbanization. This represents a threat to many natural forests in the country. Studies show that Kenya has lost approximately 50,000 ha of the forest which translates to over US \$19 million [18]. In response, the government initiated several policy reforms aimed at promoting sustainable forest management. However, there is a need to amplify strategies and policies for deadwood conservation.

\section{The Context for Deadwood in Kenya's Gazetted Natural Forests}

Kenya is a multiparty democracy geographically located in East Africa. Administratively, following the enactment of the 2010 Constitution, the country has a devolved system comprising 47 county governments and one national government. Since attaining independence in 1963, the country has made several social economic strides. The population of the country stands at 47 million people and is projected to grow at the rate of $2.3 \%$ annually [18]. The urbanization rate is $30 \%$ with over $70 \%$ of the population relying on biomass energy resources. Forests are increasingly being recognized as important for in the wider socioeconomic transformation of the country as demonstrated by their reference in key development documents such as Vision 2030 and the Constitution of Kenya 2010 which establishes a 10\% tree cover threshold for the country.

In order to contextualize deadwood resources in Kenya's forest management, in this paper, the term "forest" will be defined first and then be extended to describe the forest under study. A forest in Kenya is defined as land which has been declared or registered as a forest or woody vegetation growing in close proximity in an area of over 0.5 hectares. This definition encompasses a forest in the process of establishment, woodlands, and thickets, whereas a natural forest or an indigenous forest which is the subject of this paper refers to a forest which has come into place as a result of natural regeneration with trees primarily native to Kenya $[18,19]$. Forest land represents an important land use option in Kenya as shown in Table 1. However, from Table 1, it can be seen that forest land reduced significantly up to the year 2000 , but after the policy and legislative reforms that occurred around 2005 where the Forest Act, 2005, was enacted, the forest land rose to 4413 ha in 2015 . The decline in forest cover had been attributed to complex development realities of those times marked by weak enforcement of policies, institutional weaknesses by forest actors, and lack of public participation in forest management [18].

The gazetted natural forest types under discussion in this paper are shown in Table 2 which include the western rainforests, montane forests, coastal forests, and dry forests of Kenya (Table 2) which are under the management of the national government through Kenya Forest Service (KFS), a state corporation in the Ministry of Environment and Forestry. These forests are not evenly distributed in the country as shown in Figure 1. The northeastern part of the country has less coverage compared to the western, central, and coastal regions of the country. Mangrove forests are confined in the coastal region along the Indian Ocean. Natural forests in central parts of the country are located around Mt. Kenya and the Aberdares (Figure 1).

Nevertheless, overall, the country has an estimated forest cover of 7.2\% based on the national projection from the 2010 forest cover data $[17,18]$. Kenya has about 1.64 million ha of 
TABLe 1: Land use area in Kenya (1000 ha), 1990-2015.

\begin{tabular}{lccccc}
\hline Land use & 1990 & 2000 & 2005 & 2010 & 2015 \\
\hline Forest land & 4724 & 3557 & 4047 & 4230 & 4413 \\
Crop land & 9258 & 9661 & 9868 & 10,072 & 10,276 \\
Grassland & 41,522 & 41,654 & 41,496 & 41,080 & 126 \\
Settlement & 57 & 87 & 109 & 1044 & 143 \\
Other lands & 1004 & 1574 & 1035 & 1485 & 1053 \\
Wetland & 1472 & 1504 & 58,037 & 58,037 & 1488 \\
Total area & 58,037 & 58,037 & 58,037 \\
\hline
\end{tabular}

Source: National Strategy for $10 \%$ forest cover in Kenya [20].

TABLe 2: Forest types in Kenya.

\begin{tabular}{|c|c|c|c|}
\hline Forest type & Forest subtypes & $\begin{array}{c}\text { Approximate area } \\
(\mathrm{Ha})\end{array}$ & $\begin{array}{l}\% \text { of total } \\
\text { forest area }\end{array}$ \\
\hline $\begin{array}{l}\text { Western } \\
\text { rainforests }\end{array}$ & Natural forest (mixed indigenous-Kakamega and Nandi forests) & 144,615 & 3.5 \\
\hline \multirow{2}{*}{$\begin{array}{l}\text { Montane } \\
\text { forests }\end{array}$} & $\begin{array}{l}\text { Natural forests (mixed indigenous) which include Mt. Kenya, Aberdares, Mau, } \\
\text { Cherangany, Mt. Elgon, Matthews Ranges, and Chyulu Hills }\end{array}$ & $1,359,860$ & 32.9 \\
\hline & Bamboo & 85,693 & 2.1 \\
\hline \multirow{2}{*}{ Coastal forests } & $\begin{array}{c}\text { Natural forest (mixed indigenous trees) (Arabuko Sokoke, Dakatcha, Boni, Shimba } \\
\text { Hills, and Kaya) }\end{array}$ & 295,871 & 7.2 \\
\hline & Mangroves & 48,522 & 1.2 \\
\hline \multirow[t]{2}{*}{ Dryland forests } & $\begin{array}{c}\text { Natural forest (mixed indigenous trees) (hilltops in Eastern and Northern Kenya } \\
\text { and Lake Victoria regions) }\end{array}$ & $1,875,316$ & 45.4 \\
\hline & Riverine forests & 135,231 & 3.3 \\
\hline $\begin{array}{l}\text { Forest } \\
\text { plantations }\end{array}$ & Public and private forests & 186,716 & 4.5 \\
\hline
\end{tabular}

Source: National Strategy for 10\% forest cover in Kenya [20].

gazetted forest areas and about 100,000 ha of trust lands [22]. Public or gazetted natural forests cover an area of 905,357 ha [23]. The country's closed-canopy forests are concentrated in the moist mountainous areas where, coincidentally, human population and agricultural production activities are concentrated [24]. In the semiarid region, there are closedcanopy forests on isolated hills and along the riverine. Generally, Kenya's natural forest vegetation in public gazetted forests which comprises the forests under study in this paper consists of closed-canopy indigenous forests, woodlands, bushlands, and wooded grasslands as shown in Table 2 [25]. These forests are rich in species diversity. Some estimates indicate that Kenya's forests harbor ca. 6000 species of higher plants and 875 and 1097 different butterflies and birds, respectively [24]. The vegetation types highlighted in Table 2 are defined by climatic, edaphic, and biotic factors and incidences of fire occurrence. Fortunately, despite the proportionately small area covered by closed-canopy forests (Table 2) in relation to the overall country's surface area, forests continue to play a significant role by providing a wide variety of goods and services needed for human development [18, 25-27]. Unfortunately, most of these forests' ecosystem functions are not reflected as contributing to the country's gross domestic product (GDP) [28, 29]. Forests contribute goods and services worth ca. 7 billion Kenya shillings to the economy. In addition, the sector directly employs 50,000 people and another 300,000 indirectly $[24,28,30,31]$. Moreover, forests are valued for religious and cultural practices, and some are important habitats for plant and animal species [24]. There appears to be emerging forest management as the country transforms towards a middleincome country, but from the preceding discussion, it is evident that forest resources in the country are important in promoting human advancement and socioeconomic development. Therefore, it is essential to put in place measures to ensure these forests are sustainably managed for present and future generations.

However, to provide useful lessons on improving the recognition of deadwood in the natural forests highlighted in Table 2 and Figure 1, it will be essential first to understand how forest management has evolved in the country. Historically, forest management, including the management of natural forests in Kenya, dates back to 1895 when the country was declared a British Protectorate [32]. Forest management has passed through a series of stages (precolonial, colonial, and decolonization) and now in a devolved system under participatory forest management where livelihoods are integrated with forest management [32]. Notably, each stage of forest management was dependent on the social, economic, and political realities of the time. However, the forest demarcation objectives in the colonial period were largely geared toward generating revenue for the then forest department (government) through timber and minor forest products. In the postcolonial era, the objectives of forest management were catchment protection, industrial forestry development, and protection from encroachment by local 


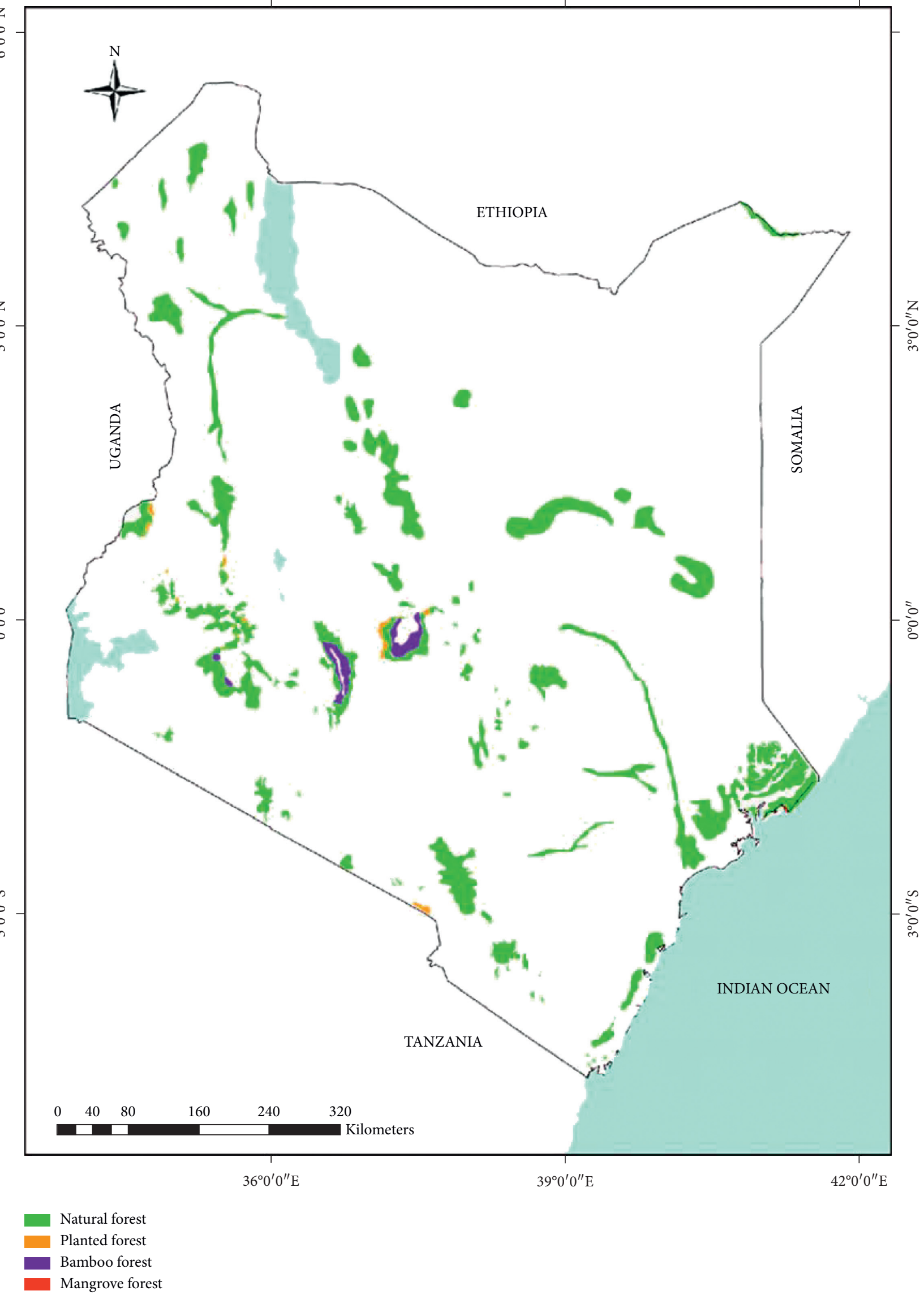

FIGURE 1: Map of Kenya showing the distribution of natural forests. Source: National Forest Program Secretariat [21]. 
communities [24]. In the postcolonial era, the realization of forest management objectives demanded that forest managers religiously apply sustainable forest management tools, which include Technical Orders of 1996 prepared by the then Forest Department (FD). In the context of natural forest restoration and regeneration, the "orders" highlight that "in order to get our natural forests restocked, natural regeneration will be used fully whenever it occurs (p. 3.1.00)." The "orders" further highlight that where a valuable species regenerates naturally, the area is marked off and a compartment register is opened for the species. As part of the tending and maintenance of regeneration, the technical orders demand that climbers and parasites be removed. Other competitions should also be removed based on the management objective apart from removing the overhead cover that may suppress the growth of the "valuable species." On the one hand, the authors observe that this preferential treatment of some natural forest components was sound and largely geared toward promoting valuable timber species for commercial purposes. On the other hand, this discriminatory management practice could disregard other forest components such as less commercially viable tree species and deadwood in the forest ecosystem, which harms their ecologically sustainable management. With this hindsight, the authors intend to share lessons on the management of natural forests in the case of deadwood.

Nevertheless, the current forest policy and legislative initiatives and discourses appear to be supporting the ecologically sustainable management of natural forests with greater emphasis on social equity through participatory forest management by advancing benefit sharing with the adjacent forest communities [24]. However, in general, studies show that these initiatives are primarily driven by utilitarian and preservationist paradigms. The preservationist approach entails excluding protected areas from extractive activities [31,33]. According to Wambugu et al. [24], this preservationist approach to forest management falls under the passive "unmanaged forest nature reserve" category mainly relevant to the national parks' forests. Most natural forests are managed under conservation systems that cut across passive and active management approaches, where high natural forests fall under passive management. Woodlands are between low and moderate management categories, while forest plantations are implemented under intensive short-rotation forestry management.

Unfortunately, the approach to resource protection either through preservation or protection appears to have constrained local communities' access, utilization, and control of the fundamental resource that supports their livelihoods [24]. However, with the emerging management approaches supported by new legislation, forest management can be guided by the paradigm behind true conservation in allowing sustainable direct (extractive and nonextractive) and indirect activities within designated ecosystems [31, 33]. Based on this paradigm, an attempt to implement it in the area under forest reserves needs to be made where natural forests could be managed under the medium "combined objective forestry." In contrast, the plantation areas could be managed under the high "intensive even-aged forestry" tending to the intensive "short-rotation forestry" forest management approach. The new forest management paradigm calls for improved forest governance, devolution, sustainable forest management, partnerships, and collaboration with the state and nonstate actors, including the adjacent communities [34]. The authors observe that these paradigm changes can improve deadwood recognition and enhance the ecologically sustainable management of natural forests where local communities derive net social benefits. Besides, these development strides represent an efficient response to emerging issues that could enable the sector to contribute to the country's economic growth and poverty alleviation goals in line with the global forest principles. These approaches in forest management have legacies that date back to the precolonial and colonial era.

Historically, the first formal forest policy was prepared in 1957 and revised in 1968 as Sessional Paper No. 1 of 1968. This policy focused on the management and conservation of forests on public land. Implementation of the 1968 policy was supported by the Forest Act Cap 385 of 1969. However, due to growing concerns about sustainability and specifically the conservation and sustainable management of biodiversity, a revised policy and legislation was prepared, which led to the enactment of Forest Act No. 7 of 2005. Later, following the enactment of the 2010 Constitution, which introduced devolved governance, entrenched further sustainable development paradigms in the country. Also, the need to align forest laws with the 2010 Constitution led to the development of Draft Forest Policy 2020 and the repealing of the Forest Act, 2005, by the Forest Conservation and Management Act, 2016, with prospects of enhancing sustainability. Robust forest management principles have been laid out, including applying an ecosystem approach in the management of natural forests driven by utilitarian and preservationist paradigms. Besides, the increased calls for decentralization in forest management decision-making led to the introduction of more progressive paradigms such as participatory forest management as a way of entrenching and reconciling both social equity and efficiency in natural forest management toward sustainable forest management.

\section{Ecologically Sustainable Forest Management}

Historically, the need for environmental sustainability arose from the growing global levels of tropical deforestation in the 1990s and the need to integrate forestry management with the objectives of biodiversity conservation [35-37]. In the quest for this sustainability, concepts such as sustainable forest management (SFM) emerged, which shifted the focus on forest management from mere wood production to the production of other forest resources as well [24]. In contrast with traditional wood-based forest management approaches, SFM offered greater flexibility to incorporate social, economic, and environmental goals in forest management $[38,39]$. Similar efforts within the framework of environmental conservation based on the Convention on Biological Diversity (CBD) led to the development of the ecosystem 
approach concept as a framework for holistic conservation of all types of forest ecosystems [40-43].

Surprisingly, to date, deforestation continues despite the existence of these novel conceptualizations [44]. Also, implementation of the widely endorsed SFM and related concepts remains challenging partly because measuring sustainability is a daunting task. Studies show that the definition of SFM and other derivatives of sustainable development is open to many interpretations and questioning $[45,46]$. Thus, it is challenging to create sustainability indicators. Consequently, ongoing discourses in the scientific community are fast converging on other concepts such as ecologically sustainable forest management (ESFM). ESFM refers to the regeneration and restoration of natural forests by targeting all ecosystem and forest components. The concept has its origins in Australia, where forest management entails a holistic approach that targets both market and nonmarket values of forests for present and coming generations [47, 48].

The primary goals of ESFM are to preserve the vigor of forested woodlands and ecosystems in a manner that maintains ecological integrity and processes that ensure there is a sustainable balance in ecological interactions. However, studies appear to indicate that forest vitality is challenging to quantify, but it is usually assessed by forest growth and physiological measurements. Forest biological diversity encompasses trees, other woody and nonwoody plants, animals, biotechnologically produced resources, and microorganisms that inhabit forest areas. There are several levels for considering biological diversity, including the ecosystem, landscapes, species, populations, and genetics. However, perhaps most important, for this paper, is the emphasis that complex interactions can occur within and amongst these levels resulting in different processes and disturbances. The evolutionary disturbances that cause biodiversity changes include climate change, fire, and forestlevel competition. The diversity of forest ecosystems (in both biotic and abiotic features) results in high adaptation levels needed for biological diversity. Therefore, within specific natural forests, the preservation of biological processes relies on maintaining their ecological variability [49]. This forest variability generates ecosystem services that provide social benefits, including contribution to the general socioeconomic development. For example, net social benefits are generated through employment and value addition to forest products [49].

In a rapidly urbanizing world, it is quite challenging to meet ecologically sustainable forest management requirements while completely meeting the society's socioeconomic development requirements because of the growing unsustainable energy demands. At times, forest value addition processes and activities involve the use of huge amounts of biomass energy resources derived from the already threatened biological resources, thus affecting the achievement of ecologically sustainable forest management.

\section{Deadwood and Ecologically Sustainable Management of Natural Forests}

Deadwood is important in the bioeconomy and ecologically sustainable management of natural forests. On the forest floor, it is created in a number of complex ways that may be a combination of both natural and anthropogenically induced causes. Existing literature shows that, in natural forests, droughts, storms, insect disease, microorganisms or other biotic stresses, and fire have been linked to damaging trees and creating deadwood with greater gatherings near canopy openings and in old-growth stands [50]. Gaps created by fallen or dead trees resulting from the highlighted natural disturbances can leave behind deadwood edifices, promoting heterogeneous flora recovery [51]. According to Thorn et al. [4], these deadwood structures are vital for biodiversity, forest recovery, and ecologically sustainable forest management.

Moreover, studies show that, by the end of the $20^{\text {th }}$ century, deadwood had already been recognized as a habitat for insects [4]. From these studies, some specialized insect biota has been found to require the presence of specific mycological species that are in turn linked with particular kinds of deadwood [52] or dead trees of specific species and a certain width and deterioration phase [53]. Deadwood has also been associated with promoting biodiversity at sophisticated trophic stages through expanding the availability of nutrition, providing shelter and resting points [4, 12, 54-61]. However, measurement of below-ground deadwood and determination of how much deadwood should remain on or in the forest floor remain a challenging issue for most forest managers and scientists in the quest for ecologically sustainable forest management [15]. Nonetheless, deadwood constitutes an important carbon component in natural forest's biodiversity [4]. Unfortunately, in general, Thorn et al. [4] and Chojnacky and Heath [62] and emerging literature on the topic indicate that there is a significant reduction in the amount of deadwood in natural forests due to fuelwood and biomass stump removal, selective logging for high-value old trees, creation of firebreaks, reduction of fuel load during fire management, and charcoal production [63-66]. Interestingly, the literature validates the above findings regarding human interference by highlighting that the hidden sources of natural forest disturbances that usually follow habitat loss are driven by more complex socioeconomic factors, including population growth, policy failures, increasing consumption, technological changes, market failure, and improper awareness of biodiversity values [67-69].

Other studies appear to agree with the above findings in the literature by indicating that, in general, the causes of biodiversity loss are largely anthropogenic, especially sanctioned by the way humans produce and consume food and energy resources and the blatant disregard of the environment that is embedded in unsustainable economic development models [70]. Furthermore, studies show that, in the wake of existential threats such as climate change largely attributed to unsustainable anthropogenic activities, the planet has lost approximately $68 \%$ of animals, including mammals, birds, amphibians, and other life forms, between 1970 and 2016, representing 94\% drop in the living planet index for the tropical subregions of America [70]. In addition, it is shocking that $99 \%$ of all life forms that ever existed on the earth are now extinct. Moreover, existing literature reveals that $80 \%$ of life forms remain 
undocumented [69]. Hochkirch et al. [71] concurred with these findings and cautioned that existential threats will continue to rise if concerted efforts are not initiated to mitigate biodiversity loss and climate change. In a disturbing revelation, the study notes that only a small proportion of birds, mammals, and amphibians have greater than $80 \%$ of their species assessed, but perhaps most importantly and perhaps with more direct links to the need for this study, Hochkirch et al. [71] indicated that the lack of species assessments is attributed to the lack of expertise, lack of human capacity, lack of funding, lack of public awareness, and political will. However, interestingly, in general, there appears to be concurrence that biological diversity is critical for the overall health of the planet's ecosystem. Therefore, to enhance planetary health, a cultural and systematic shift in human production and consumption methods is required to protect biodiversity sufficiently. These findings provide credence to this study and the need to enhance ecologically sustainable forest management as a way of conserving global forest biodiversity. Besides, forest management interventions and disturbances have been acknowledged as the key factors contributing to deadwood pools on the forest floor.

\section{Strategies for Achieving Ecologically Sustainable Management of Deadwood}

Existing literature has demonstrated that presently, the quantities of deadwood in natural forests are unstable. Interestingly, even though there are limited studies on the impacts of reducing deadwood in these forests through enrichment planting, deadwood is generally removed from forests in the form of fuelwood and stump biomass removal [64], selective logging targeting old trees [72], and deadwood collection for bioenergy [65]. Anthropogenic disturbances such as the creation of firebreaks are also associated with deadwood removal [63]. Due to the removal, Thorn et al. $[4,65]$ indicated that the quantities of deadwood are on the decline, and this poses a threat to the biological diversity of natural forests contrary to the objectives of ESFM. Studies from European forests indicate that the diversity of saproxylic insects depends on dead or decaying wood. Their diversity is positively connected with the amount of deadwood available in the forest. Hence, it is important to incorporate more robust and sustainable deadwood management strategies [73].

Sustainable deadwood management strategies have been implemented in many Scandinavian countries [74]. Deadwood management strategies in Europe and most Scandinavian countries have largely involved putting in place measures and policies aimed at implementing the concept of bioeconomy where research and innovation in biological sciences are used as the basis for all economic activities and public benefit. Two dimensions are pursued in bioeconomy strategies and policies: firstly, the biotechnology innovation perspective where biological resources such as deadwood are identified in view of their immense contribution to sustainable economic growth value chains, employment, energy supply chains, and high standards of living and secondly, the resource substitution perspective that emerged largely as a result of efforts aimed at addressing climate change concerns, especially the following realization of the impacts of using fossil-based fuels. Studies report that efforts to promote bioeconomy-related policies and strategies that include deadwood have been largely successful in many European countries [75-78]. However, there are some slight variations in strategies and policies in terms of focusing. In some countries, strategies focus strictly on bioeconomy, whereas in others, strategies focus on aspects such as biotechnology and renewable energy. However, the underlying principles guiding these conceptual developments revolve around promoting resource use efficiency and the need to avoid the generation of waste, as shown in Figure 2. Bioeconomy is also linked to other approaches for implementing sustainable development such as the circular economy and green economy, which are increasingly being promoted as new ways of creating value and ultimately prosperity through extending the product life and relocating wastes from the end of the supply chain to the beginning and thus increasing resource use efficiency by using a resource more than once (Figure 2). These resource-use desires are in line with the goals of sustainable development, which encourages reusing raw materials as many times as possible to produce energy or other products and may be extended to the sustainable management of deadwood resources. However, the concept of bioeconomy has been contested on account of "green washing" and "the fundamental critique." [80, 81] Regardless of criticisms, bioeconomy-related concepts that aim at promoting resource substitution and promoting biotechnology have a strong relationship with ecologically sustainable management of deadwood resources in view of the underlying principles that seek to ensure sustainability and can also be adopted in developing countries.

Nonetheless, in order to achieve ecologically sustainable forest management, two broad approaches are applied: active and passive enrichment [4]. Passive deadwood enrichment involves forest preservation processes where logging and other forms of anthropogenic disturbances are completely excluded from fostering naturally produced deadwood. Even though desirable, passive management may be challenging in young natural forests or formerly managed stands where the rate of deadwood formation is slow. However, passive management of deadwood may not be practicable in all regions because of the varying commercial interests and societal demand for timber and fuelwood [82]. Nevertheless, protected natural forests with no anthropogenic disturbances are more desirable for deadwood management and ESFM [83]. Active enrichment entails leaving parts of trees such as crowns or stem sections within harvest units [84]. Active enrichment has been found to increase deadwood amounts on the landscape level in young and formerly managed forests, thus enhancing biodiversity [85]. Other strategies involve the use of explosives and partial cutting of tree crowns [86]. Active and passive enrichment strategies can be applied in the tropics, where deadwood amounts increase if logging residues remain after selective logging [87].

Natural forest management strategies that involve deadwood enrichment can also be classified based on 


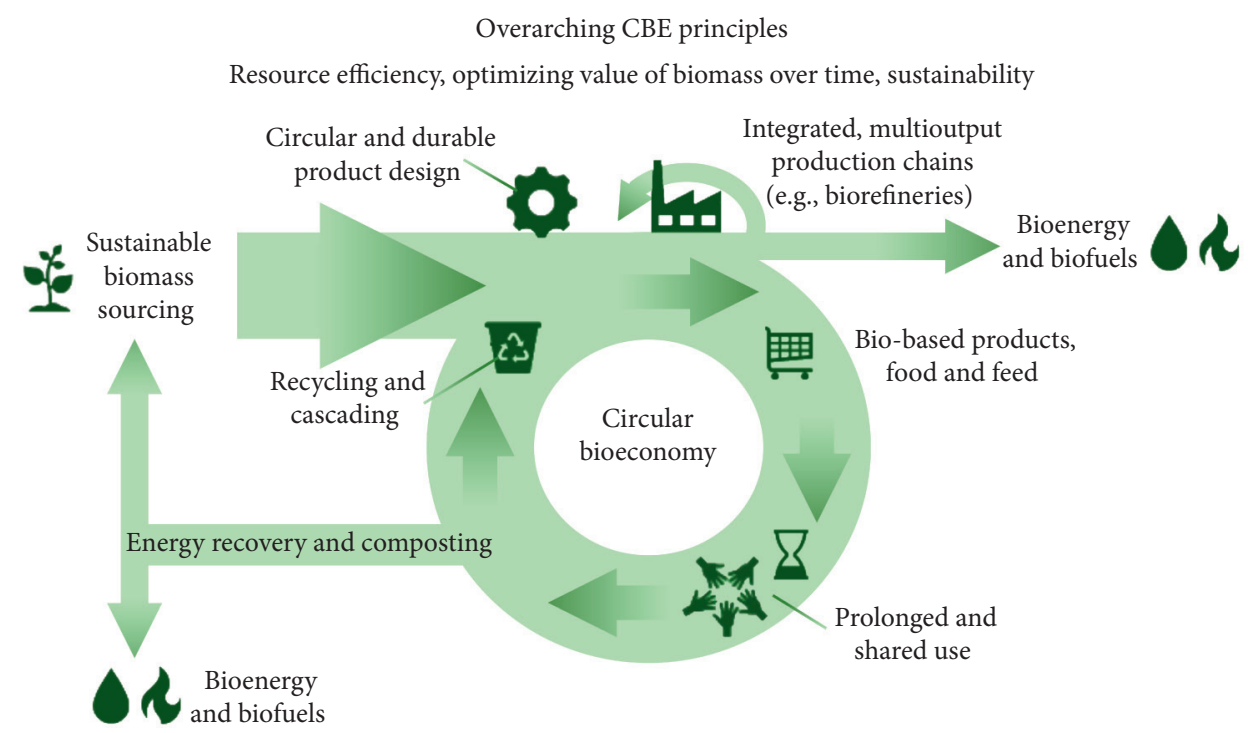

Figure 2: Circular bioeconomy and its elements in relation to deadwood resources. Source: Stegmann et al. [79].

silvicultural systems that are heavily economic based or ecological based. The economic basis focuses on production factor utilization and economic return [88]. In contrast, ecologically based systems focus on modifying natural conditions [89-91]. Duncker et al. [38] proposed forest management strategies based on forest management intensity that reflect a full range of social, economic, and environmental aspects of sustainability. Duncker et al. [38] found that regardless of forest management objects, the actions, including no action, affect forest status and processes and influence the biodiversity and the ecological conditions of a forest. Duncker et al. [38] thus proposed and described five forest management approaches, which were arranged along a gradient of the intensity of resource manipulation (from "passive" to "active"). Table 3 summarizes the five forest management approaches that have a strong correlation with the management of deadwood in a natural forest, which may also apply to deadwood resources' ecological management.

Moreover, even though there appear to be no studies that have established the optimum amounts of deadwood associated with each of these forest management approaches, the passive unmanaged nature reserve, the low close-tonature forestry, and the medium combined objective forestry may be the most appropriate approaches in relation to deadwood in natural forests and the general forest biodiversity and ecological functioning because there are minimal anthropogenic manipulations and natural regeneration appears to be the preferred type of forest restoration as shown in Table 3. However, the authors also note that even though other approaches such as combined objective forestry may be favorable for increasing the amount of deadwood on the forest floor, there is a need to exercise caution in order to balance risks of losing biological diversity and the economic impacts of biodiversity conservation. For instance, where natural forest stands are located adjacent to production forest stands, deadwood may enhance the proliferation of insect pests that may damage production forest stands leading to huge economic losses. Most Scandinavian countries have developed natural forest management policies that are cognizant of these risks. In Finland, forest management policy is oriented towards preserving deadwood by promoting biodiversity conservation through favoring mixed stand-in management, which favors increased amounts of deadwood under strict forest protection protocols. Biological diversity and deadwood are conserved by tree felling and application of silvicultural measures that leave deadwood and retention trees in a given habitat [92]. Interestingly, despite adopting such strict forest protection approaches, the country appears to be balancing very well between utilization of wood fuel from deadwood and biodiversity conservation. The use of wood-based fuels has been increasing since the 1990s and now accounts for $20 \%$ of the country's total consumption of energy [92]. Up to $75 \%$ of total energy consumption by forest industries is met by deadwood resources, making them self-sufficient.

Moreover, there appears to be a significant difference between deadwood volumes in managed and unmanaged forests in Finland, but generally, the mean volume is $5.8 \mathrm{~m}^{3} /$ ha. Natural forests in Finland have deadwood volumes ranging between 40 and $70 \mathrm{~m}^{3} / \mathrm{ha}$. However, these mean values cannot be reliable over a long period of time due to the differences in decomposition rates of deadwood [93].

Interestingly, it appears that the application of the deadwood manipulation approaches highlighted in Table 1 is achieving different deadwood yields in different countries depending on their development contexts. For instance, in Swedish forests, the average deadwood volume was estimated to be ca. $24 \mathrm{~m}^{3} /$ ha which appears to be far below the expected natural values of $80-120 \mathrm{~m}^{3} /$ ha [94]. Moreover, many European forests have revealed over 36 thresholds with $10-80 \mathrm{~m}^{3} / \mathrm{ha}$ for boreal and lowland forests and 10 to $150 \mathrm{~m}^{3} / \mathrm{ha}$ for montane forests [95]. Other studies estimate that the mean deadwood volume for European forests was 
TABLE 3: Forest management approaches with relevance to deadwood management.

\begin{tabular}{|c|c|c|c|c|c|c|c|}
\hline $\begin{array}{l}\text { Forest } \\
\text { management } \\
\text { approach }\end{array}$ & Naturalness & Tree improvement & $\begin{array}{c}\text { Type of } \\
\text { regeneration }\end{array}$ & $\begin{array}{c}\text { Integration of } \\
\text { nature } \\
\text { protection } \\
\end{array}$ & $\begin{array}{l}\text { Tree } \\
\text { removal }\end{array}$ & Final harvest & Maturity \\
\hline $\begin{array}{l}\text { Passive } \\
\text { unmanaged } \\
\text { nature reserve }\end{array}$ & $\begin{array}{c}\text { Natural } \\
\text { vegetation }\end{array}$ & None & $\begin{array}{l}\text { Natural } \\
\text { regeneration/ } \\
\text { succession }\end{array}$ & High & None & None & $\begin{array}{c}\text { No } \\
\text { intervention }\end{array}$ \\
\hline $\begin{array}{l}\text { Low close-to- } \\
\text { nature forestry }\end{array}$ & $\begin{array}{l}\text { Native site } \\
\text { adapted }\end{array}$ & $\begin{array}{c}\text { No genetic } \\
\text { modification or tree } \\
\text { breeding }\end{array}$ & $\begin{array}{l}\text { Natural } \\
\text { regeneration or } \\
\text { planting }\end{array}$ & High & Stem & $\begin{array}{l}\text { Single stem or } \\
\text { group selection, } \\
\text { irregular } \\
\text { shelterwood }\end{array}$ & $\begin{array}{l}\text { Long rotation } \\
\text { (MAI) }\end{array}$ \\
\hline $\begin{array}{l}\text { Medium } \\
\text { combined } \\
\text { objective } \\
\text { forestry }\end{array}$ & $\begin{array}{c}\text { Tree species } \\
\text { suitable for } \\
\text { site }\end{array}$ & $\begin{array}{c}\text { Planting material } \\
\text { from tree breeding } \\
\text { but not genetically } \\
\text { modified }\end{array}$ & $\begin{array}{l}\text { Natural } \\
\text { regeneration, } \\
\text { planting, and } \\
\text { seeding }\end{array}$ & High & $\begin{array}{l}\text { Stem and } \\
\text { crown }\end{array}$ & $\begin{array}{l}\text { All possible seed } \\
\text { trees, strip, or } \\
\text { group } \\
\text { shelterwood }\end{array}$ & $\begin{array}{l}\text { Long rotation } \\
\text { (MAI) }\end{array}$ \\
\hline $\begin{array}{l}\text { High intensive } \\
\text { even-aged } \\
\text { forestry }\end{array}$ & $\begin{array}{c}\text { Tree species } \\
\text { suitable for } \\
\text { site }\end{array}$ & $\begin{array}{l}\text { Tree breeding } \\
\text { allowed, no genetic } \\
\text { modifications }\end{array}$ & $\begin{array}{l}\text { Natural } \\
\text { regeneration, } \\
\text { planting, and } \\
\text { seeding } \\
\end{array}$ & Medium & $\begin{array}{l}\text { Whole } \\
\text { tree }\end{array}$ & $\begin{array}{l}\text { All possible } \\
\text { clear-cut, long } \\
\text { rotation } \\
\text { preferable } \\
\end{array}$ & $\begin{array}{l}\text { Short rotation } \\
\text { (financial } \\
\text { rotation) }\end{array}$ \\
\hline $\begin{array}{l}\text { Intensive short } \\
\text { rotation forestry }\end{array}$ & Any species & $\begin{array}{l}\text { Tree breeding and } \\
\text { genetic } \\
\text { modification used }\end{array}$ & $\begin{array}{l}\text { Planting, seeding, } \\
\text { and coppicing }\end{array}$ & Low & $\begin{array}{l}\text { Whole } \\
\text { tree and } \\
\text { residuals }\end{array}$ & $\begin{array}{l}\text { All possible } \\
\text { (coppice clear- } \\
\text { cut) }\end{array}$ & $\begin{array}{l}\text { Short rotation } \\
\text { (financial } \\
\text { rotation) }\end{array}$ \\
\hline
\end{tabular}

Source: adopted from Wambugu et al. [24].

$20.5 \mathrm{~m}^{3} / \mathrm{ha}$, while without the Russian Federation, the amount drops to a paltry $10 \mathrm{~m}^{3} /$ ha. Studies have established that these deadwood amounts vary depending on the vegetation zone, rate of decay, stand volume, and forest type [96].

Nevertheless, deadwood studies are increasingly shifting focus beyond mere biodiversity conservation and are now focused on exploring the link between deadwood and climate change, with interesting results being generated. For instance, a study conducted in Europe that sought to establish the amount of carbon in deadwood found that intensively managed forests have lower mean levels of deadwood carbon, while multifunctional management approaches resulted in the highest levels of deadwood carbon in the context of climate change [58]. Other studies have explored the rates of accumulation of deadwood on the forest floor and the attendant impacts of climate change on forest regeneration. For instance, Mazziota et al. [97], while modeling the effects of climate change and management effects on deadwood in boreal forests, found that the rising global temperatures would speed up tree growth leading to increased accumulation of deadwood. Still, the accompanying rise in decomposition rates will lead to reduced amounts of species-specific deadwood resources, thus impacting overall forest biodiversity in terms of species evenness and richness. Therefore, all active approaches to the sustainable management of deadwood resources ( $\mathrm{Ta}-$ ble 3) must exercise caution to ensure that displacement or replacement of deadwood must reflect the type of trees that must be planted in a given natural forest in order to avoid its extinction or disappearance from these forests. Besides impacting on the overall forest biological diversity, such active manipulation processes may have long-term consequences on how a particular natural forest is influenced by climate change. However, further studies that explore the impact of climate change on the rates of decomposition of deadwood in other forest types will be important in order to boldly carry forward this deadwood discourse into the context of ecologically sustainable forest management and hence the need for this study.

Nevertheless, there is an urgent need to raise the level of consciousness and awareness on the importance of bioeconomy and the ecologically sustainable management of deadwood resources in natural forests. According to Thorn et al. [4], many environmental education programs mention the importance of deadwood for conserving biodiversity in a general but rather superficial way mainly because of the low profile that is accorded to deadwood. In the light of this, there is an urgent need for developing educational programs targeting the health of natural forests in general and deadwood in particular through campaigns and visits. Also, it appears that deadwood's biodiversity lacks appealing characteristics for the nonscientific community who occasionally feel rarely represented in conservation efforts [97-100]. These findings represent a major challenge for deadwood's importance in the general public and amongst scientists, policymakers, and forest managers and demonstrate the need for expanding the media and cultural linkages in deadwood awareness. However, the recent advances in "win-win" biocentric approaches to forest management as exemplified by the increasing need to involve adjacent forest communities in forest management and the growing feminist paradigms in the society are increasingly changing the classical way foresters have viewed good sustainable forest management practices. There appears to be a growing propensity towards including the recognition of deadwood resources in natural forest management [100-104].

Interestingly, despite these paradigm changes, the existing literature indicates that the public appears less 
concerned about the status of deadwood despite enjoying the cultural ecosystem services supported by deadwood resources in many natural forests [4]. Studies have shown that the aesthetic beauty of a landscape is affected by the density and diversity of trees, including deadwood [105], which attracts people to visit forests. Unfortunately, forests with large amounts of deadwood are viewed as chaotic, untidy, and destroyed [88, 106-110]. However, Pastorella et al. [111] showed that the preferred type of forests related to different management forms of deadwood (unmanaged forests, closeto-nature forests, extensively managed forests, and intensively managed forests). The study found that both components of deadwood were not perceived negatively by tourists and the public. More than $60 \%$ of respondents prefer unmanaged forests and close-to-nature managed forests, and $40 \%$ of respondents prefer intensively managed forests where the deadwood is removed during the treatments $[58,112,113]$. Nonetheless, more studies will be required to establish how these relatively new concepts shape the dynamics and management of deadwood resources in natural forest ecosystems, hence the need for this study in Kenya's context.

In general, the educational programs aimed at raising awareness of deadwood need to be fashioned to help overcome the seemingly negative attitude presented above and address unsustainable energy resources' demands. Different countries seem to be adopting different awareness strategies based on their development contexts. For instance, Thorn et al. [4] reported that deadwood educational programs applied in Europe include guided forest visits with groups of people and rely on informative outdoor exhibits focusing on deadwood species, nutrient cycles, and the natural decay of large, old trees. Furthermore, the study notes that such educational forest visits could enhance conservation-related knowledge and long-term retention of gained knowledge. Other more promising approaches include adapting the flagship-species concept to environmental education programs [99]. A particular taxon is highlighted and used to stimulate interest in the ecological importance of deadwood. Studies have established that flagship species from higher trophic levels in saproxylic food webs, such as birds or mammals, could foster positive attitudes toward deadwood, for example, the barbastelle bat (Barbastella barbastellus), which uses deadwood and forest stands decimated by bark beetles as nesting, roosting, and foraging sites [114]. Moreover, flagship species can be used in children's books and other educational programs to communicate deadwood preservation, thus reaching a much bigger audience. However, Thorn et al. [4] pointed out that the efficacy of deadwood-specific programs remains mostly unknown, and to ensure efficacy, such programs must be subject to quantitative evaluation, measuring success via the presence and quality of deadwood and associated biodiversity, in addition to the human dimensions of forest ecosystems. Greater focus on interdisciplinary research is also needed to identify knowledge gaps and divergent opinions on deadwood and be targeted with specific educational programs such as the use of video games [115]. Hochkirch et al. [71] proposed the use of the International
Union for Conservation of Nature's (IUCN) red list of endangered species as a source of reliable information in order to create more holistic, robust, and effective conservation actions. Moreover, the study recommends the need to revive exploratory field research to facilitate knowledge transfer, link taxonomy information to conservation information, improve the global collation of spatial biodiversity data, mapping of spatial threat data, automation of preassessments, creating biodiversity monitoring programs for lesser-known taxa, and mobilization of funds to fill knowledge gaps.

\section{Challenges to the Ecologically Sustainable Management of Deadwood in Kenya}

As already outlined, public natural forests are principally managed by the government through the Kenya Forest Service to provide many ecosystem services, for instance, the provision of fuelwood to adjacent forest communities [24]. Moreover, it has been documented that more than $10 \%$ of households living within $5 \mathrm{~km}$ of forest reserves depend on them for subsistence resources [18]. Also, forests represent up to $3.6 \%$ of the country's GDP. However, inconsistencies in reporting on the share of the forest's contribution to GDP need to be resolved if forests are rated highly and sustainably conserved in the country. More rigorous analysis is required to increase forests' and tree valuation based on their overall economic value to increase conservation consciousness amongst individuals and communities. There are indications that such valuations will be conducted in the country following a recent assessment of the Mau Forest Complex, Cherangany Hills, and Mt. Elgon ecosystems, which established the total economic value (TEV) of the three water tower ecosystems at Kshs. 362 billion per year (ca. $5.0 \%$ GDP in 2017), as portrayed in Table 4.

Moreover, the existing literature shows that the public per capita wood demand was $1 \mathrm{~m}^{3}$ every year, and yet, public forests have a sustainable wood fuel yield of $0.9 \mathrm{~m}^{3}$ per ha per year [23]. With the current population standing at 47 million in 2019 , the per capita wood demand rose from $38 \mathrm{~m}^{3}$ in 2009 to $47 \mathrm{~m}^{3}$ in 2019 . Wood fuel sourced from state forests is the common type of biomass energy in Kenya, contributing ca. $70 \%$ of the public energy demand, while about $90 \%$ of Kenyan country families use wood fuel or charcoal [23]. Additionally, wood fuel meets over $93 \%$ of rustic family energy needs, while charcoal is the dominant energy source in metropolitan families [116]. Firewood sourced from gazetted forests is mainly used for cooking, water heating, house heating, lighting, and other home businesses. Households are the most important category in wood energy consumption, with an estimated consumption of 6.5 tons per household per year [117]. The second highest wood fuel consumer is the cottage industries, including brickmaking, tobacco curing, fish smoking, jaggery, and bakeries. Others include small restaurants/hotels and kiosks and learning institutions. Given the importance of cottage industries in income and employment generation and wealth creation for the rural population, their energy requirements need specific attention to ensure their sustainability. On average, most 
Table 4: Total economic value of the Mau, Cherangany, and Mt. Elgon ecosystems.

\begin{tabular}{lccc}
\hline Type of ecosystem service & Ecosystem services & Annual contribution (KShs.) & Contribution to TEV (\%) \\
\hline & Timber and nontimber & $22,941,590,363$ & 6.33 \\
& Food production & $634,770,000$ & 0.18 \\
Provisioning & Water & $3,427,027,000$ & 0.95 \\
& Hydroelectricity & $11,983,679,000$ & 3.31 \\
& Biodiversity & $5,712,786,000$ & 1.58 \\
Subtotal & Tourism & $9,300,000,000$ & 2.57 \\
& Water flow & $53,999,852,363$ & 0.82 \\
Regulating & Water-quality regulation & $2,960,143,000$ & 0.32 \\
& Carbon sequestration & $1,155,366,000$ & 48.75 \\
Subtotal & Oxygen generation & $176,657,067,000$ & 32.69 \\
Supporting & Microclimatic regulation & $118,461,049,000$ & 0.58 \\
& Soil conservation & $2,099,161,000$ & 83.16 \\
Subtotal & Nutrient conservation & $301,332,786,000$ & 0.29 \\
Subtotal & Pollination & $1,060,000,000$ & 1.24 \\
Grand total & & $4,499,000,000$ & 0.26 \\
\hline
\end{tabular}

Note: 1 US\$ is ca. Kshs. 100. Source: National Strategy for 10\% forest cover in Kenya [20].

cottage industries use between 20 and $30 \%$ of the total operating costs on energy, which is mainly from wood [118]. Despite this significance, wood fuel demand and supply information remains scanty and has a high degree of uncertainty, making wood energy policy formulation a daunting task [113].

The above complex development challenges revolving around the use of wood for energy and other uses have had somewhat far-reaching impacts on Kenya's forests. According to Wass [119], the presence of stumps in forests represents an important indicator of fuelwood use and, by extension, deadwood's presence. Wass [119] acknowledges that even though firewood removal may be practical in the context of developing countries such as Kenya, unregulated removal may have some far-reaching negative consequences on overall biodiversity conservation, especially in natural forests. For example, the report indicates that, in some parts of Kakamega Forest, a western rainforest (Table 2), holenesting forest birds declined because dead branches in which they make nest holes have been removed, and one part of Kakamega showed no signs of wood-eating termites because there was no deadwood on the ground. Furthermore, it is common under these conditions for fuelwood collectors to ringbark trees so that there are future deadwood supplies, thereby accelerating offtake. In the coastal and Nairobi forests, Brachylaena huillensis is the preferred fuelwood and the most important wood used in carving items for sale to tourists. Species-focused removal of this tree has led to the loss of all large trees in Arabuko Sokoke and severe declines in the Nairobi forests. Some special commercial importance trees may be so reduced in numbers so that their populations may no longer be viable. For example, Milicia excelsa (mvule) has been exploited for timber from the coastal forests for decades, and Vitex keniensis (Meru oak) and Olea capensis (Cape olive) are in a similar state of decline in the montane forests. It is not clear to what extent forest bird species have been lost in Kenya due to habitat degradation and fragmentation caused by logging. However, some bird species have not been reported in Kakamega rainforest for several years. These findings by Wass [119] are mainly in agreement with other studies that have established that much of the closed-canopy forests have been depleted due to internal and external influences resulting in significant biodiversity losses [120]. Besides, even though policies and legal frameworks governing wood production and utilization in Kenya aim to ensure sustainability, their effectiveness has not been realized as there is an imbalance where supply is lower than demand. The supply is low because possible optimal targets have not been reached due to inadequate management practices, low forest areas that are continually being lost to agriculture, settlements, and other developments. At the same time, demand is high because of the increasing population, excessive dependence on wood, and wasteful processing and utilization technologies [120]. These factors affect sustainable deadwood management in natural forests as well. Moreover, forest fires have been widely reported in Kenya's Forest Resource Assessment Reports by the Food and Agricultural Organization of the United Nations as the greatest cause of damage to natural forests by burning biodiversity [112]. However, the impact of these fires on the quantity and biological diversity of deadwood resources remains unexplored. Kenya's Forest Resource Assessment Report for 2015 appears to reinforce Wass's [119] findings on a scarcity of deadwood information and its impacts. The report provides default figures for deadwood in Kenya's forests. It estimated that the proportion of deadwood in standing biomass was 0.0177 without giving any further information on inventory protocols used and 
parameters that were assessed. Thus, it is important to awaken the consciousness on sustainable management of deadwood resources in the country and devise measures for ensuring its sustainability. The initial steps would involve upscale efforts towards ecologically sustainable forest management where all biodiversity resources in natural forests, including birds, animals, and others, are documented in efforts aimed at establishing scientific records for each natural forest in Kenya, hence the need for this study.

\section{Deadwood Awareness Initiatives in Kenya}

There are many policy and extra policy initiatives that are currently under implementation to encourage the ecologically sustainable management of deadwood resources in gazetted natural forests and the general environment at large. For example, Kenya's National Biodiversity Strategy and Action Plan for the period 2019-2030 recognizes and outlines many causes of biodiversity loss, including deadwood. For example, the action plan identifies cultural attitudes toward deadwood as having a strong bearing on species and biodiversity conservation status. Even though studies have not been done to establish this claim, Kenya's government appears to have rolled out several initiatives aimed at addressing her biodiversity conservation concerns.

Nonetheless, the sustainable conservation of deadwood resources in Kenya is broadly guided by the National Biodiversity Strategy and Action Plan, whose provisions for the period 2019-2030 are in line with the Aichi targets and the objectives of the Convention on Biological Diversity (CBD). The document considers that biodiversity conservation is essential for our existence and basically valuable in its own right. The document outlines educational programs' centrality through workshops, seminars, public meetings, conferences, "seeing-is-believing" tours, and participation in national and international days with themes related to biodiversity conservation. Mass media platforms such as radio, television, newspapers, sectoral websites, short message service, social media, and e-mail complement the educational platforms and enable broader audience access to repackaged information [121]. However, studies on the effectiveness of these outreach programs in deadwood and natural forest conservation are needed. Also, there are many stakeholders involved in the management of natural forests in the country. They include the media, higher-learning institutions (colleges and universities), faith-based organizations, private sector agencies, and government agencies [18]. Cognizant of this fact, in 2019, the state's forest manager (Kenya Forest Service-KFS) enhanced the existing PFM framework's multistakeholder capabilities by introducing a collaboration framework that allows greater participation of corporate bodies and individuals in forest management, including awareness creation.

Other initiatives that extend to deadwood awareness include implementing the national strategy for achieving and maintaining $10 \%$ forest cover, which covers the rehabilitation of natural forests, which are deadwood sources under examination in this study. The strategy document spells out a raft of measures for ensuring sustainability, including public awareness, education, and sensitization on the importance of forests through media campaigns, print, electronic, and social media platforms. However, perhaps more radically, the strategy proposes reviewing primary and secondary schools' teaching curriculum to include sustainable forest management, organizing field days and exhibitions, and showcasing sustainable deadwood management events. In addition, the strategy aims at improving wood conversion and utilization of alternative energy sources through processes such as ecolabeling, use of efficient cookstoves, use of alternative energy sources such as solar, wind, liquid petroleum gas (LPG), biogas, and briquettes, and provision of incentives and awards to promoters of best practices as well as research in forest restoration. Moreover, Kenya submitted her Nationally Determined Contributions (NDC) with regard to carbon emissions, where the country increased her target to $32 \%$ from the initial 30\% [122]. A number of robust strategies are highlighted in the NDC, including cutting down on the use of biomass energy resources, which appear to be used by many Kenyans, whereas these efforts are laudable, and sustainable deadwood management-specific programs do not feature prominently in these key forest management policy documents. Thus, it will be important to raise consciousness and reemphasize the centrality of deadwood in the context of the ecologically sustainable management of natural forests in Kenya.

\section{Discussion}

Natural forests are important biodiversity reservoirs with many organisms that create biological balance globally $[1,2,25,121]$. The ecological and biological balance created is important for supporting human existence and development through the provision of vital ecosystem services $[18,25,28,30,31]$. Hence, discourses on the need to integrate sustainable forest-based economic development and biodiversity conservation have dominated the globe, leading to the emergence of new forest management concepts. The quest for new conceptual changes is mainly being driven by the weaknesses of the sustainable development theory and its derivatives such as SFM. SD and its derivatives have been contested on account of being open to many interpretations, and there is a problem with creating sustainability indicators $[45,46]$.

Consequently, other concepts such as ESFM are increasingly becoming popular, albeit in certain regions of the globe in the context of forest management. The primary goals of ESFM are maintaining the vitality of forest ecosystems, which covers ecological processes within forests, maintaining the biological diversity of forests, and managing the net social benefit derived from the mixture of forest uses $[47,48]$. Interestingly, this study has revealed that the above goals are similar to the goals of other emerging concepts such as bioeconomy, green economy, and circular economy that seek to promote sustainable forest management in the wake of climate change [75-79].

Results from Kenya exemplify the above global-level findings of the importance of biodiversity conservation. The 
country has a huge and quite diverse natural forest resource base (Figure 1) that is contributing to the balance between the environment and socioeconomic transformation (Tables 2-4; Draft Forest Policy [18]; National Strategy towards 10\% Tree Cover 2019; MEF [122]; Wambugu et al. [24]). Interestingly, Kenya also appreciates the changing conceptual environment of natural forest management by developing, reviewing, and adopting relatively robust forest management policies such as participatory forest management, which is mainly compatible with ESFM in many respects. However, perhaps more interestingly in this study, the highlighted conceptual changes are increasingly changing the classical way foresters have viewed good forest management practices in Kenya and beyond [100-104]. These policy changes are also increasingly being applied in the sustainable management of natural forests.

Deadwood in natural forests plays an important role in advancing discourses on the above sustainable forest management conceptual changes because it is a critical component in the process and function of natural forests with direct links to enhancing the achievement of ESFM, bioeconomy, and circular economy $[4-6,9,10,13,51,54,57,59,61,62,113]$. Also, even though the global literature has extensively defined deadwood from the perspective of ESFM as reported by Mark et al. [14], Hezron [9], Wu et al. [16], and Merganičová et al. [15], forest policy guidelines in Kenya do not explicitly define deadwood. Hence, no specific sustainable deadwood management guidelines are in place to ensure its sustainable conservation in the wake of complex development challenges such as loss of biological diversity and climate change. However, based on the deadwood definition given by $\mathrm{Wu}$ et al. [16] and Merganičová et al. [15] where deadwood encompasses barks and firewood on the forest floor, deadwood is only being implied in the Forest Conservation and Management Act [19] through a list of forest produce where barks and firewood are mentioned as indicated in the following; forest produce includes bark, animal droppings, beeswax, canes, charcoal, creepers, earth, fiber, firewood, frankincense, fruit, galls, grass, gum, honey, leaves, flowers, limestone, moss, murram, soil, myrrh, peat, plants, reeds, resin, rushes, rubber, sap, soil, seeds, spices, stones, timber, trees, water, wax, withies, and such other things as may be declared by the Cabinet Secretary to be forest produce for this act, p.8.

Unfortunately, Wass [119] appears to be the only scientific authority in Kenya that has cited deadwood, but in the context of biodiversity conservation. While cautioning on the negative impacts of fuelwood removal on deadwood and the regeneration of natural forests, Wass [119] illustrated that fuelwood removal does not necessarily lead to biodiversity loss. Still, high levels of removal could cause biodiversity loss, whereas this study agrees with Wass [119]; the authors observe that this finding was published almost two decades ago. A lot may have changed over time, especially with regard to socioeconomic advancements that have occurred in the country. Moreover, since 1995 when the study was undertaken, there is a scarcity of proceeding studies focusing on deadwood. Hence, we cannot ascertain the notion of "high levels of removal" as suggested by
Wass [119]. However and perhaps most importantly, Wass [119] gave some examples of natural forests where biodiversity loss may have occurred due to deadwood removal. It may have affected ESFM, bioeconomy of natural forests, and the circular economy in the country. The study identified the Kakamega rainforest, coastal, Nairobi, and montane forests as affected forests. These forests represent crucial natural forest ecosystems listed in Table 2 and are linked to promoting ecological balance, human well-being, and economic development. Oduor and Githiomi [120] reinforced these biodiversity loss fears in the context of unsustainable fuelwood extraction in Kenya's natural forests. However, perhaps more importantly, these examples of biodiversity loss, which extend to deadwood, reinforce the findings in reviewed global-level literature and the central themes of this paper with regard to the importance of deadwood and the need to put in place robust and actionable specific programs targeting sustainable management of deadwood resources.

The Forest Conservation and Management Act [19] spells out somewhat robust natural forest management objectives where deadwood falls under this discussion. The objectives include conservation of water, soil and biodiversity, riparian and shoreline protection, cultural use and heritage, recreation and tourism, sustainable production of wood and nonwood products, carbon sequestration and other environmental services, education and research purposes, habitat for wildlife in terrestrial forests, and fisheries in mangrove forests. In general, these objectives are in line with the three goals of ESFM, and thus, deadwood management, in this case, could fall under the "sustainable production of wood and nonwood products objectives." However, to date, there are no guidelines for the sustainable production of wood and nonwood products from natural forests in Kenya, which affects the ESFM of deadwood in these forests. Besides, it is shocking that key forest management policy documents reviewed in this study, for instance, the Draft Forest Policy [18], the National Strategy for Achieving and Maintaining 10\% Forest Cover by 2022, the Forest Management Technical Orders of 1996, and the National Biodiversity Strategy and Action Plan for the period 2019-2030, do not have explicit provisions on sustainable management of deadwood resources. There are only general provisions for sustainable management and rehabilitation of natural forests hence posing a real great threat to deadwood management in the context of ESFM. On the contrary, global-level literature has highlighted the centrality of sustainable deadwood management-specific guidelines in countries with robust natural forest management regimes such as Finland, Sweden, and other European countries and how these resources are contributing to bioeconomy and circular economy in these countries [4, 58, 65, 75-79, 92, 95].

It is therefore essential to reiterate that although critical policy guidelines on natural forest management and available literature on the contribution of deadwood to the three goals of ESFM in Kenya appear scanty, global literature has shown that deadwood is essential for maintaining the biological and ecological balance through enhancing natural forest vitality and health and biodiversity and contributes to 
net communal social benefits in a circular economy. In this regard, many developed countries have developed robust deadwood management strategies, including active and passive enrichment to conserve deadwood resources $[4,74,84,85]$. Moreover, the reviewed literature indicates that both active and passive enrichment with deadwood are applicable in many situations, including in the tropics [87]. Kenya is a tropical African country, and hence, these approaches may be relevant and applicable. However, it is essential to conduct location-specific studies on their practicability, given its complex biological and socioeconomic circumstances. Besides, other countries have actively pursued, created, and managed deadwood resources in their natural forests using explosives and partial cutting of tree crowns, as illustrated by Speight [86], and retention felling in natural forests as in the case of Finland $[92,93]$. Table 3 has summarized other forest management approaches that could apply to natural forests that harbor deadwood as a critical component. However, the combined objective forestry (Table 3 ) appears to be the most compatible with the robust management of deadwood resources in the context of ecologically sustainable management of forests.

Unfortunately, despite the good examples of sustainable forest management interventions highlighted above, the reviewed literature suggests that deadwood in natural forests appears to be declining globally, presenting a challenge to ESFM [4, 65]. The key factors identified to be causing the decline are anthropogenic forest management processes and disturbances through fuelwood collection, charcoal production, firebreak management, and unsustainable logging practices and other biotic stresses $[63,64,66,72]$. Similarly, in Kenya, apart from what was observed almost two decades ago by Wass [119], deadwood appears to be declining in most natural forests because forest management in the country appears to have been greatly influenced by the legacies of colonial forest management objectives, which were fixated on merchantable wood production in plantation/production forests for the government's revenue generation with utter disregards for deadwood resources from natural forests in view of its perceived low economic or no commercial value. To underscore this point, currently, the policy guidelines on the conservation and enrichment of natural forests allow minimal deadwood removal in the form of firewood for domestic purposes [24]. Interestingly, there is no threshold for estimating the so-called "minimal deadwood removal" in the form of fuelwood by adjacent forest communities, thus begging the question, "how minimal is minimal removal?" The reviewed literature shows that fuelwood from natural forests is extracted by adjacent forest communities upon payment for a monthly fuelwood license (MFL) worth Kshs. 100 (US \$1) to the government through the Kenya Forest Service. In the current fuelwood extraction practice, as long as one has a valid MFL, one is only allowed to pick "dead" and "fallen" wood from the forest floor without any restriction on the frequency of extraction. Moreover, due to inadequacy of staff and other forest management challenges at the Kenya Forest Service, especially the presence of few forest enforcement officers, this study observes that it is difficult to monitor whether those with valid MFL only pick "dead and fallen wood." Also, it is difficult for adjacent forest communities fetching firewood to define the term "dead" in the context of firewood while on the forest floor. With this hindsight, the proper definition of what constitutes deadwood is required because the reviewed literature has indicated that even though deadwood may be literally dead from the face of it, it may be providing a habitat for other rare and endangered biological organisms in the forest. Therefore, could this "minimal removal of fuelwood" management approach of natural forests in Kenya be akin to trying to manage what we do not know given the vital role played by deadwood in ecologically sustainable forest management and related concepts such as bioeconomy and circular economy? Nonetheless, in Kenya's context, it can be generally understood that the minimal removal of fuelwood is based on the edicts of the concept of sustainable development and its derivatives, which have been found problematic $[45,46]$. However, this study observes that caution should be exercised in view of emerging conceptual changes and what earlier studies have documented regarding natural forests in the country. For instance, Wass [119] reported that degradation and exploitation of natural forests for fuelwood had significantly impacted four important tree species in the country, namely, Brachylaena huillensis, Milicia excelsa, Vitex keniensis, and Olea capensis. In this study, the authors observe that, without a robust biological diversity monitoring system for these species, the country risks driving these important biological resources into extinction if robust strategies and policies are not put in place to check the rising per capita firewood removal from natural forests. To highlight the impending biodiversity risk, a quick fact checks in the IUCN red list which identifies Brachylaena huillensis and Milicia excelsa as near-threatened tree species with unspecified population trends in the wild, including natural forest areas. Vitex keniensis is classified as an endangered species, and its population across the world biosphere was declining fast, according to the IUCN. Even though Olea capensis is listed as a tree species of least concern with a stable population trend in the IUCN red list, there is a need to put in place some robust measures that will guarantee its existence in the future in the context of ecologically sustainable forest management and related approaches. In addition, even though, the highlighted "minimal firewood removal" policy provision may be appropriate for Kenya, given the current complex socialeconomic development realities where over $70 \%$ of the population uses biomass energy resources and the demand for it appears to be rising. With the growing human population now standing at 47 million people, which is reportedly increasing by $2.3 \%$ per annum, the demand for deadwood from natural forest ecosystems is likely to increase, leading to loss of biodiversity and a severe deadwood management crisis. Existing scientific literature such as Oduor and Githiomi [120] has reinforced these findings by demonstrating that although policies and legal frameworks governing wood (including deadwood such as fuelwood) production and utilization in Kenya aim at ensuring sustainability, their effectiveness has not been realized as there exists an imbalance where supply is lower than demand 
occasioned by population growth, wasteful processing, and utilization technologies amongst other complex sociotechnical factors. However, in this context, unlike other countries where deadwood is actively managed with robust guidelines, Kenya's scenario may be dire due to the absence of knowledge about the importance, quantification, and sustainable management strategies for deadwood.

Furthermore, the country's overall environmental challenges may worsen with the risk of escalating biodiversity loss occasioned by unsustainable biomass energy resources' exploitation. Mugo [117] noted that even though wood energy is important in the country, wood fuel data on supply and demand are scarce and characterized by a high degree of uncertainty that makes it difficult to undertake relevant wood energy planning and policy formulation. Moreover, households have been cited as the greatest consumers of wood using approximately 6.5 tons per household per year, multiply that consumption level with 12.2 million households in the country, and the wood requirement is unimaginable in an environment where the quantity of available deadwood resources in our natural forests is unknown. Besides the threats of losing the country's biological diversity through burning for energy needs, the country risks escalating the threat of climate change by failing to achieve her carbon emission targets in the recently submitted Nationally Determined Contributions in accordance with the Paris Agreement. However and perhaps most importantly, Mugo [117] and Ngui et al. [118] recommended the need to reevaluate energy requirements to ensure sustainability, hence reemphasizing the central themes of this paper. Interestingly, the reviewed literature appreciates this policy, sociotechnical, and economic development complexities facing the country. However, more importantly, they acknowledge that these challenges have the potential to cause habitat loss, and this may also encompass loss of deadwood, especially in the context where the population appears to be growing rapidly, such as Kenya and other developing countries [67, 68, 123]. Therefore, urgent and decisive action is needed to develop ecologically sustainable deadwood management guidelines to avert an impending natural forest management crisis in the country.

Nevertheless, all is not lost as it may appear to be that Kenya's development scenario offers a number of opportunities for enhancing ESFM and related approaches such as bioeconomy with the focus on deadwood. The existing PFM framework where people's livelihoods and forest conservation objectives are integrated with natural forest management objectives appears to be more compatible with the three goals of ESFM and associated approaches, and they could be further integrated for greater conservation of deadwood in the country. Developing PFM strategies with specific programs focusing on deadwood may enhance the sharing of ecosystem services derived from deadwood resources with the adjacent forest communities, thereby enhancing their ESFM by promoting the net social benefits that accrue to communities. This approach could foster greater recognition and acceptance of deadwood by the public. In fact, Wambugu et al. [24] demonstrated that communities' recognition and involvement in processes that involve the sharing of ecosystem services improve forest management outcomes toward greater sustainability. However, a natural resource benefit-sharing policy lacks in the country, and the country lacks data on the total economic value of all natural forests similar to data contained in Table 4 . These are real challenges that could slow sustainable deadwood management in the country through PFM.

Participatory forest management represents a good opportunity for challenging the negative attitude, indifference, and the seemingly low profile that appears to be accorded to deadwood, as indicated by Thorn et al. [4, 65]. These studies indicated that the public is always less concerned with deadwood's presence despite enjoying most of its cultural ecosystem services [4]. Daniel et al. [105] showed that the density of deadwood affects aesthetic beauty from an ecotourism perspective for most forest goers. Other studies have shown that forests with large amounts of deadwood are unattractive to the public and are viewed as chaotic, untidy, and ruined [106-110]. Similarly, in Kenya, even though not as explicit as in the studies mentioned earlier, the National Biodiversity Strategy and Action Plan for 2019-2030 identifies negative attitude and complex cultural factors among the key issues hindering biodiversity conservation and which could be extrapolated to deadwood management as well. The current natural forest management approach, which incorporates PFM, can challenge and overcome these challenges if well implemented. PFM is implemented in the country through participatory forest management plans, where management programs are developed based on a given forest's biological and socioeconomic composition and realities. Most management plans which appear to be premised on the ecosystem approach principles have the scientific and education program which could be leveraged for sustainable management of deadwood resources. However, the creation of specific educational programs that target deadwood in natural forests has been lauded and considered most appropriate in reemphasizing the importance of deadwood by many findings [4]. In this paper, the authors emphasize that specific deadwood programs may be preferable in the participatory forest management plans because the existing scientific and educational programs' efficacies remain mostly unknown due to the absence of studies and may not be relied upon for the promotion of deadwood awareness. Besides exploring the opportunities presented by the framework of collaboration between KFS and corporate bodies where universities and other interested parties could be brought on board to conduct deadwood management studies, it will also be essential to escalating specific deadwood programs through workshops, seminars, public meetings, conferences, "seeing-is-believing" tours, and participation in national and international days with themes related to biodiversity. Mass media platforms such as radio, television, newspapers, sectoral websites, social media, and e-mail are indicated in the National Biodiversity Strategy and Action Plan for 2019-2030. There is a need for full implementation of the above programs because similar approaches have been supported by the existing literature $[71,99,115]$. These outreach programs appear to be appropriate for deadwood management because their 
implementation will likely impact various demographic groups present in Kenya. However, studies on the demographic preferences for messages on deadwood should be conducted to determine their effectiveness and relative advantages. Besides, due to the anticipated impacts of sustained deadwood outreach programs, there may be a need to create a compensation scheme for those who lose livelihood in the fuelwood value chain. Such strategies were proposed by Thorn et al. [4], even though applied in the European context, but subject to studies, and they could be replicated in Kenya [124-128].

\section{Conclusion and Recommendations}

Deadwood in natural forest ecosystems plays an important role in maintaining a balance in natural forest processes and functions. However, natural forest degradation through the removal of deadwood, even though widely neglected, results in considerable biodiversity loss and alters natural forests with the risk of escalating the negative impacts of climate change. Kenya's case has substantiated these findings from the perspective of ESFM and demonstrated that reducing forest degradation in the future will require the restoration of deadwood and increasing public awareness and consciousness on the importance of deadwood for biodiversity conservation and maintaining forest ecological functions. To reduce further degradation and promote ESFM, this paper recommends

(1) Conducting location-specific studies on the importance of deadwood, quantity, public attitudes, management strategies, and impacts on biodiversity conservation

(2) Scientifically documenting the biological diversity of natural forests

(3) Reviewing primary and secondary schools' teaching curriculum to include sustainable forest management

(4) Undertaking the total economic valuation of natural forests

(5) Developing specific guidelines for sustainable management of deadwood in natural forest ecosystems

(6) Enacting the natural resource benefit-sharing legislation which will foster sharing of ecosystem services, including those provided by deadwood

(7) Reviewing the existing tools for sustainable forest management such as participatory forest management plans and Technical Orders of 1996 to incorporate robust and specific deadwood management programs with clear, measurable indicators

(8) Introducing public awareness and educational programs such as campaigns and field visits that emphasize the importance of deadwood management and developing a location-specific deadwood resuscitation pilot project
(9) Provision of incentives for enhancing the use of alternative energy sources apart from fuelwood and reducing the use of biomass energy resources

(10) Providing compensation for those who lose livelihood as a result of collapsing the fuelwood value chain

(11) Enhancing international cooperation in the enforcement of guidelines for ecologically sustainable forest management

(12) Conducting studies to evaluate the effectiveness of the current deadwood management awareness approaches

(13) Conducting studies to gauge people's perceptions towards deadwood resources and the application of biotechnology in its sustainable management

(14) Expanding the cultural and media linkages in sustainable conservation of deadwood resources

\section{Data Availability}

The forest type data used to support the findings of this study are included within the article.

\section{Conflicts of Interest}

The authors declare that they have no conflicts of interest.

\section{Acknowledgments}

This work was supported by the Ministry of Education of the Republic of Korea and the National Research Foundation of Korea (NRF-2020S1A5C2A01092978).

\section{References}

[1] M. E. Assessment, Ecosystems and Human Well-Being, Island Press, Washington, DC, USA, 2005.

[2] R. S. de Groot, R. Alkemade, L. Braat, L. Hein, and L. Willemen, "Challenges in integrating the concept of ecosystem services and values in landscape planning, management and decision making," Ecological Complexity, vol. 7, no. 3, pp. 260-272, 2010.

[3] Department of Agriculture, Water and the Environment, The Concept of Ecologically Sustainable Forest Management, Australian Government, Australia, 2020, https://www. agriculture.gov.au/forestry/policies/rfa/about/esfm.

[4] S. Thorn, S. Seibold, A. B. Leverkus et al., "The living dead: acknowledging life after tree death to stop forest degradation," Frontiers in Ecology and the Environment, vol. 18, no. 9, pp. 505-512, 2020.

[5] J. N. Stokland, J. Siitonen, and B. G. Jonsson, Biodiversity in Dead Wood, Cambridge University Press, Cambridge, UK, 2012.

[6] F. L. Bunnell, I. Houde, B. Johnston, and E. Wind, "How dead trees sustain live organisms in western forests," in Proceedings of the Symposium on the Ecology and Management of Dead Wood in Western Forests, pp. 291-318, United States Department of Agriculture, Forest Service General Technical Report PSW-GTR-181, Berkeley, CA, USA, 2002. 
[7] J. Humphrey and S. Bailey, "Managing Deadwood in Forests and Woodlands," Forestry Commission, Edinburgh, UK, 2012.

[8] S. J. Kontogianni and G. F. Peterken, "Deadwood in British forests: priorities and a strategy," Forestry, vol. 71, no. 2, pp. 99-112, 1998.

[9] E. Hezron, Deadwood Production and Decomposition Rate of Acacia Tortilis and Acacia Nilotica Around University of Dodoma, Tanzania: The Ecological Role of Termites in Semiarid Regions, Doctoral Dissertation, The University of Dodoma, Dodoma, Tanzania, 2017.

[10] J. Müller, A. Jarzabek-Müller, H. Bussler, and M. M. Gossner, "Hollow beech trees identified as keystone structures for saproxylic beetles by analyses of functional and phylogenetic diversity," Animal Conservation, vol. 17, no. 2, pp. 154-162, 2014.

[11] C. M. Shackleton, "Annual production of harvestable deadwood in semi-arid savannas, South Africa," Forest Ecology and Management, vol. 112, no. 1-2, pp. 139-144, 1998.

[12] S. Seibold, C. Bässler, R. Brandl et al., "Experimental studies of dead-wood biodiversity-a review identifying global gaps in knowledge," Biological Conservation, vol. 191, pp. 139-149, 2015.

[13] S. Seibold, C. Bässler, P. Baldrian et al., "Dead-wood addition promotes non-saproxylic epigeal arthropods but effects are mediated by canopy openness," Biological Conservation, vol. 204, pp. 181-188.

[14] C. V. Mark, J. R. Malcolm, and S. M. Smith, "An integrated model for snag and downed woody debris decay class transitions," Forest Ecology and Management, vol. 234, no. (1-3), pp. 48-59, 2006.

[15] K. Merganičová, J. Merganič, M. Svoboda, R. Bače, and V. Šebeň, "Deadwood in forest ecosystems," Forest Ecosystems-More than Just Trees, InTech Book, London, UK, 2012.

[16] J. Wu, D.-x. Guan, S.-j. Han, M. Zhang, and C.-j. Jin, "Ecological functions of coarse Woody Debris in forest ecosystem," Journal of Forestry Research, vol. 16, no. 3, pp. 247-252, 2005.

[17] J. K. Kagombe, J. Kiprop, D. Langat et al., "Socio-economic impact of forest harvesting moratorium in Kenya," KEFRI, Kenya, 2020.

[18] Draft Forest Policy for Kenya, "Policies on indigenous forest management," 2020, http://www.environment.go.ke/wpcontent/uploads/2020/06/Draft-Forest-Policy-19May-2020-. pdf.

[19] Forest Conservation and Management Act, http://kenyalaw. org:8181/exist/kenyalex/actview.xql?actid=No.\%2034\%20of \%202016/on/20th/January/2021, 2016.

[20] Kenya National Strategy for 10\% Forest Cover, http://www. environment.go.ke/wp-content/uploads/2019/08/Strategyfor-10-Tree-Cover-23-5-19-FINAL.pdf, 2019.

[21] National Forest Program (NFP) Secretariat, Report on Data Mining, Generation, Verification, Formulation and Completion Data, NRIT, Nairobi, Kenya, 2015.

[22] P. Wass, Kenya's Forest Resource Assessment, FAO Publication, Rome, Italy, 2000.

[23] Ministry of Environment and Natural Resources, "Analysis of wood demand report," 2012, http://www. kenyaforestservice.org/documents/redd/Analysis\%20of\% 20Demand\%20and\%20Supply\%20of\%20Wood\%20Products \%20in\%20Kenya.pdf.

[24] E. W. Wambugu, G. O. Obwoyere, and B. K. Kirui, "Effect of forest management approach on household economy and community participation in conservation: a case of Aberdare Forest Ecosystem, Kenya," International Journal of Biodiversity and Conservation, vol. 10, no. 4, pp. 172-184, 2018.

[25] KFS (Kenya Forest Service), Draft Forest Policy, Kenya Forest Service, Nairobi, Kenya, 2014.

[26] H. J. Beentje, “The forests of Kenya," Mitteilungen aus dem Institut für Allgemeine Botanik Hamburg, Hamburg, Germany, 1990.

[27] N. Koike, R. Margoluis, K. H. Redford, and J. G. Robinson, "Improving the practice of conservation: a conceptual framework and research agenda for conservation science," Conservation Biology, vol. 16, no. 6, pp. 1469-1479, 2002.

[28] L. Frei, Valuing Forest Resources in East Africa. Workshop Report on Reducing Biodiversity Loss at Selected Cross-Border Sites in East Africa, Economics Component Technical Report No. 1. 2nd - 4th April, 2001, Arusha, Tanzania: GEF/UNDP/ FAO Cross Border Biodiversity Project, 2001.

[29] J. Manyindo, "Diversifying commercial forest values for forest conservation and improved livelihoods on the ssese islands," Forestry Series \# 3, Uganda Wildlife Society, Kampala, Uganda, 2003.

[30] IUCN (International Union for Conservation of Nature), Forest Cover and Reserves in Kenya. Policy and Practice, IUCN-EARO, Nairobi, Kenya, 1996.

[31] KFMP (Kenya Forestry Master Plan)Ministry of Environment and Natural Resources, Nairobi, Kenya, 1994.

[32] E. Mugo, C. Nyandiga, and M. Gachanja, Development of Forestry in Kenya (1900-2007): Challenges and Lessons Learnt, Kenya Forestry Working Group, Kenya, 2010.

[33] P. O. Ongugo, D. Langat, V. O. Oeba et al., "A review of Kenya's national policies relevant to climate change adaptation and mitigation: insights from Mount Elgon," CIFOR, Bogor, Indonesia, Working Paper 155, 2014.

[34] S. Costa, C. Casanova, P. Lee, and P. Lee, "What does conservation mean for women? the case of the Cantanhez forest national park," Conservation and Society, vol. 15, no. 2, pp. 168-178, 2017.

[35] D. Ghai, Environment, Livelihood and Empowerment. Development and Change. Institute of Social Studies, Blackwell Publishers, Oxford, UK, 1994.

[36] R. Harrington, C. Anton, T. P. Dawson et al., "services and biodiversity conservation: concepts and a glossary," Biodiversity and Conservation, vol. 19, no. 10, pp. 2773-2790.

[37] M. Salleh, "Sustainability: the panacea for our forestry ills?" Journal of Sustainable Forestry, vol. 4, no. 4, pp. 33-43, 1997.

[38] P. S. Duncker, S. M. Barreiro, G. M. Hengeveld, T. Lind, W. L. Mason, and S. Ambrozy, "Classification of forest management approaches: a new conceptual framework and its applicability to European forestry," Ecology and Society, vol. 17, no. 4, p. 51, 2012.

[39] B. Fisher, I. Bateman, and R. K. Turner, Valuing Ecosystem Services: Benefits, Values, Space and Time., Ecosystem Services Economics (ESE), Working Paper Series No. 3. UNEP, Nairobi, Kenya, 2011a.

[40] Convention on Biological Diversity, The Value of Forest Ecosystems, CBD Technical Series No. 4, Montreal, Canada, 2001.

[41] FAO (Food and Agriculture organization of the United Nations), "Sustainable management and the ecosystem approach: two concepts, one goal. Forest management working papers. Working paper No. 25," Forest Resources Development Service. Forest Resources Division. Food and Agriculture Organization of the United Nations, Rome, Italy, 2003. 
[42] E. Nelson, G. Mendoza, J. Regetz et al., "Modeling multiple ecosystem services, biodiversity conservation, commodity production, and tradeoffs at landscape scales," Frontiers in Ecology and the Environment, vol. 7, no. 1, pp. 4-11, 2009.

[43] A. Weisser, A. Wossink, M. Kortelainen, R. Alkemade, and C. J. E. Schulp, "Trade-off analysis of ecosystem services in Eastern Europe,” Ecosystem Services, vol. 4, pp. 82-94, 2013.

[44] K. MacDicken, Ö. Jonsson, L. Piña et al., "Global forest resources assessment 2015: how are the world's forests changing?" 2016.

[45] W. N. Adger and A. Jordan, Eds., Governing Sustainability, Cambridge University Press, Cambridge, UK, 2009.

[46] M. Redclift, "Development and global environmental change," Journal of International Development, vol. 9, no. 3, pp. 391-401, 1997.

[47] O. Chikumbo, R. D. Spencer, B. J. Turner, and S. M. Davey, "Planning and monitoring forest sustainability: an Australian Perspective," Australian Forestry, vol. 64, no. 1, pp. 1-7, 2001.

[48] S. M. Davey, J. Hoare, C. Binning, and C. Bright, "Assessment of ecologically sustainable forest management for Regional Forest Agreements, "Preparing for the 21st century, pp. 235-246, 2012.

[49] Convention on Biological Diversity, "Website. Forest biodiversity programme," 2020, https://www.cbd.int/ programmes/.

[50] B. Perschel, A. Evans, and M. DeBonis, Forest Biomass Retention and Harvesting Guidelines for the Southeast, Forest Guild Southeast Biomass Working Group. Forest Guild, Sante Fe, NM, USA, 2012.

[51] M. E. Swanson, J. F. Franklin, R. L. Beschta et al., "The forgotten stage of forest succession: early-successional ecosystems on forest sites," Frontiers in Ecology and the Environment, vol. 9, no. 2, pp. 117-125.

[52] J. Weslien, L. B. Djupström, M. Schroeder, and O. Widenfalk, "Long-term priority effects among insects and fungi colonizing decaying wood," Journal of Animal Ecology, vol. 80, no. 6, pp. 1155-1162, 2011.

[53] F. Kostanjsek, P. Sebek, B. Baranova, L. Seric Jelaska, V. Riedl, and L. Cizek, "Size matters! habitat preferences of the wrinkled bark beetle, Rhysodes sulcatus, the relict species of European primeval forests," Insect Conservation and Diversity, vol. 11, no. 6, pp. 545-553, 2018.

[54] N. Dudley and D. Vallauri, "Restoration of deadwood as a critical microhabitat in forest landscapes," in Forest Restoration in LandscapesSpringer, New York, NY, USA, 2005.

[55] G. H. Kagezi, M. Kaib, P. Nyeko, C. Bakuneeta, M. Schädler, and R. Brandl, "Decomposition of tissue baits and termite density along a gradient of human land-use intensification in Western Kenya," African Journal of Ecology, vol. 49, no. 3, pp. 267-276, 2011.

[56] D. B. Lindenmayer and K. Ough, "Salvage logging in the montane ash eucalypt forests of the Central Highlands of Victoria and its potential impacts on biodiversity," Conservation Biology, vol. 20, no. 4, pp. 1005-1015, 2006.

[57] P. Martikainen, L. Kaila, and Y. Haila, "Threatened beetles in white-backed woodpecker habitats," Conservation Biology, vol. 12, no. 2, pp. 293-301, 1998.

[58] A. Paletto, I. De Meo, P. Cantiani, and F. Ferretti, "Effects of forest management on the amount of deadwood in Mediterranean oak ecosystems," Annals of Forest Science, vol. 71, no. 7, pp. 791-800, 2014
[59] S. Radu, "The ecological role of deadwood in natural forests," in Nature ConservationSpringer, Berlin, Heidelberg, Germany, 2006.

[60] T. Spribille, G. Thor, F. L. Bunnell, T. Goward, and C. R. Björk, "Lichens on dead wood: species-substrate relationships in the epiphytic lichen floras of the Pacific Northwest and Fennoscandia," Ecography, vol. 31, no. 6, pp. 741-750, 2008.

[61] L. Tillon, C. Bouget, Y. Paillet, and S. Aulagnier, "How does deadwood structure temperate forest bat assemblages?" European Journal of Forest Research, vol. 135, no. 3, pp. 433-449, 2016.

[62] D. C. Chojnacky and L. S. Heath, "Estimating down deadwood from FIA forest inventory variables in Maine," Environmental Pollution, vol. 116, pp. S25-S30, 2002.

[63] D. C. Donato, J. B. Fontaine, and J. L. Campbell, "Burning the legacy? influence of wildfire reburn on dead wood dynamics in a temperate conifer forest," Ecosphere, vol. 7, no. 5, Article ID e01341, 2016.

[64] M. Jonsell, "Effects on biodiversity of forest fuel extraction, governed by processes working on a large scale," Biomass and Bioenergy, vol. 31, no. 10, pp. 726-732, 2007.

[65] S. Thorn, C. Bässler, R. Brandl et al., "Impacts of salvage logging on biodiversity: a meta-analysis," Journal of Applied Ecology, vol. 55, no. 1, pp. 279-289.

[66] M. D. Cobb, S. Horn, S. Pokswinski, J. V. McHugh, and J. K. Hiers, "A comparison of coarse woody debris volume and variety between old-growth and secondary longleaf pine forests in the southeastern United States," Forest Ecology and Management, vol. 429, pp. 124-132, 2018.

[67] A. Gobster and D. Kaimowitz, "Rethinking the causes of deforestation: lessons from economic models," The World Bank Research Observer, vol. 14, no. 1, pp. 73-98, 1999.

[68] J. S. Brashares, C. D. Golden, K. Z. Weinbaum, C. B. Barrett, and G. V. Okello, "Economic and geographic drivers of wildlife consumption in rural Africa," Proceedings of the National Academy of Sciences, vol. 108, no. 34, pp. 1393113936, 2011.

[69] L. C. Malav, S. Kumar, and P. K. Malav, "Global status of biodiversity and threats," Biotica Research Today, vol. 2, no. 5, pp. 330-332, 2020.

[70] R. E. A. Almond, M. Grooten, and T. Petersen, "Living planet report 2020-bending the curve of biodiversity loss," Natural Resources \& Environment, vol. 35, no. 3, pp. 62-62, 2021.

[71] A. Hochkirch, M. J. Samways, J. Gerlach et al., "A strategy for the next decade to address data deficiency in neglected biodiversity," Conservation Biology, 2020.

[72] A. Ahrends, N. D. Burgess, S. A. Milledge et al., "Predictable waves of sequential forest degradation and biodiversity loss spreading from an African city," in Proceedings of the $\mathrm{Na}$ tional Academy of Sciences, vol. 107, no. 33, pp. 14556-14561, 2010.

[73] S. J. Grove, "Saproxylic insect ecology and the sustainable management of forests," Annual Review of Ecology and Systematics, vol. 33, no. 1, pp. 1-23, 2002.

[74] L. Vítková, R. Bače, P. Kjučukov, and M. Svoboda, "Deadwood management in Central European forests: key considerations for practical implementation," Forest Ecology and Management, vol. 429, pp. 394-405, 2018.

[75] BMBF, National Research Strategy Bioeconomy 2030-Our Route Towards a Biobased Economy, Federal Ministry of Education and Research (BMBF), Berlin, Germany, 2010. 
[76] EC, New Perspectives on the Knowledge-Based Bio-Economy-Conference Report, European Commission (EC), Brussels, Belgium, 2005.

[77] EU, En Route to the Knowledge-Based Bio-Economy ("Cologne Paper"), German Presidency of the Council of the European Union (EU), Cologne, Germany, 2007.

[78] J. Potočnik, New perspectives in the knowledge-based bioeconomy: transforming life sciences knowledge into new, sustainable, eco-efficient and competitive products, 2005.

[79] P. Müller, M. Londo, and M. Junginger, "The circular bioeconomy: its elements and role in European bioeconomy clusters," Resources, Conservation \& Recycling: X, vol. 6, Article ID 100029, 2020.

[80] K. Birch, "The neoliberal underpinnings of the bioeconomy: the ideological discourses and practices of economic competitiveness," Genomics, Society, and Policy, vol. 2, no. 3, pp. 1-15, 2006.

[81] K. Birch, L. Levidow, and T. Papaioannou, "Sustainable capital? The neoliberalization of nature and knowledge in the European "Knowledge-based bio-economy"' Sustainability, vol. 2, no. 9, pp. 2898-2918, 2010.

[82] A. da Silva, Y. Paillet, H. Jactel, and C. Bouget, "Deadwood as a surrogate for forest biodiversity: meta-analysis of correlations between deadwood volume and species richness of saproxylic organisms," Ecological Indicators, vol. 11, no. 5, pp. 1027-1039, 2011.

[83] W. F. Stinson, D. C. Useche, J. Rendeiro et al., "Averting biodiversity collapse in tropical forest protected areas," Nature, vol. 489, no. 7415, pp. 290-294.

[84] T. Ranius, A. Caruso, M. Jonsell, A. Juutinen, G. Thor, and J. Rudolphi, "Dead wood creation to compensate for habitat loss from intensive forestry," Biological Conservation, vol. 169, pp. 277-284, 2014.

[85] N. Roth, I. Doerfler, C. Bässler et al., "Decadal effects of landscape-wide enrichment of dead wood on saproxylic organisms in beech forests of different historic management intensity," Diversity and Distributions, vol. 25, no. 3, pp. 430-441.

[86] M. C. Swanson, Saproxylic Invertebrates and Their Conservation, Council of Europe, Europe, 1989.

[87] B. S. Carlson, S. E. Koerner, V. P. Medjibe, L. J. T. White, and J. R. Poulsen, "Deadwood stocks increase with selective logging and large tree frequency in Gabon," Global Change Biology, vol. 23, no. 4, pp. 1648-1660, 2017.

[88] K. G. Arano and I. A. Munn, "Evaluating forest management intensity: a comparison among major forest landowner types," Forest Policy and Economics, vol. 9, no. 3, pp. 237-248, 2006.

[89] C. Gamborg and J. B. Larsen, "Back to nature-a sustainable future for forestry?" Forest Ecology and Management, vol. 179, no. 1-3, pp. 559-571, 2003.

[90] P. Shyamsundar and R. A. Kramer, "Tropical forest protection: an empirical analysis of the costs borne by local people," Journal of Environmental Economics and Management, vol. 31, no. 2, pp. 129-144, 1996.

[91] R. A. M. Silvano, S. Udvardy, M. Ceroni, and J. Farley, "An ecological integrity assessment of a Brazilian Atlantic Forest watershed based on surveys of stream health and local farmers' perceptions: implications for management," Ecological Economics, vol. 53, no. 3, pp. 369-385, 2005.

[92] M. Lier and J. Parviainen, "Integration of nature protection in forest policy in Finland. INTEGRATE Country Report. EFICENT-OEF, Freiburg. The authors would like to thank two anonymous reviewers for careful review and valuable comments on the report," Pictures cover: Erkki Oksanen/ Metla EFICENT-OEF, Freiburg, Germany, 2013.

[93] N. Mikkonen, N. Leikola, P. Halme, E. Heinaro, A. Lahtinen, and T. Tanhuanpää, "Modeling of dead wood potential based on tree stand data," Forests, vol. 11, no. 9, p. 913, 2020.

[94] J. Siitonen, "Forest management, coarse woody debris and saproxylic organisms: Fennoscandian boreal forests as an example," Ecological Bulletins, vol. 49, pp. 11-41, 2001.

[95] J. Müller and R. Bütler, "A review of habitat thresholds for dead wood: a baseline for management recommendations in European forests," European Journal of Forest Research, vol. 129, no. 6, pp. 981-992, 2010.

[96] M. Lier, A. Schuck, J. Van Brusselen et al., Maintenance, Conservation and Appropriate Enhancement of Biological Diversity in Forest Ecosystems, State of Europe's Forests 2020, Europe, 2020.

[97] A. Mazziotta, M. Mönkkönen, H. Strandman, J. Routa, O.-P. Tikkanen, and S. Kellomäki, "Modeling the effects of climate change and management on the dead wood dynamics in boreal forest plantations," European Journal of Forest Research, vol. 133, no. 3, pp. 405-421, 2014.

[98] M. Barua, D. J. Gurdak, R. A. Ahmed, and J. Tamuly, "Selecting flagships for invertebrate conservation," Biodiversity and Conservation, vol. 21, no. 6, pp. 1457-1476, 2012.

[99] A. Eckelt, J. Müller, U. Bense et al., "“Primeval forest relict beetles" of Central Europe: a set of 168 umbrella species for the protection of primeval forest remnants," Journal of Insect Conservation, vol. 22, no. 1, pp. 15-28.

[100] T. Webler, S. Tuler, and R. Krueger, "What is a good Participation process? five perspectives from the public," Environmental Management, vol. 27, no. 3, pp. 435-450, 2001.

[101] A. Agrawal and K. Gupta, "Decentralization and participation: the governance of common pool resources in Nepal's Terai," World Development, vol. 33, no. 7, pp. 1101-1114, 2005.

[102] M. T. E. Mbuvi, J. O. Maua, P. O. Ongugo, C. K. Koech, R. A. Othim, and J. K. Musyoki, "Perceptions on participatory forest management impacts on poverty for selected forest adjacent communities in Kenya," ARPIP-KEFRI Project Report No. 1, 2009.

[103] P. Ongugo, J. Njuguna, E. Obonyo, and G. Sigu, "Livelihoods, natural resource entitlements and protected areas: the case of Mt. Elgon forest in Kenya," in Proceedings of the 2nd Biennial Meeting of the International Forestry Resources and Institutions (IFRI) Research Network, Kenya Forestry Research Institute (KEFRI), Nairobi, Kenya, 2002.

[104] M. A. Salam and T. Noguchi, "Factors influencing the sustained participation of farmers in participatory forestry: a case study in central Sal forests in Bangladesh," Journal of Environmental Management, vol. 74, no. 1, pp. 43-51.

[105] T. C. Daniel, A. Muhar, A. Arnberger et al., "of cultural services to the ecosystem services agenda," Proceedings of the National Academy of Sciences, vol. 109, no. 23, pp. 8812-8819.

[106] A. Arnberger, M. Ebenberger, I. E. Schneider et al., "Visitor preferences for visual changes in bark beetle-impacted forest recreation settings in the United States and Germany," Environmental Management, vol. 61, no. 2, pp. 209-223.

[107] C. G. Flint, B. McFarlane, and M. Müller, "Human dimensions of forest disturbance by insects: an international synthesis," Environmental Management, vol. 43, no. 6, pp. 1174-1186, 2009.

[108] O. Pelyukh, A. Paletto, and L. Zahvoyska, "People's attitudes towards deadwood in forest: evidence from the Ukrainian 
Carpathians," Journal of Forest Science, vol. 65, no. 5, pp. 171-182, 2019.

[109] J. Rathmann, P. Sacher, N. Volkmann, and M. Mayer, "Using the visitor-employed photography method to analyse deadwood perceptions of forest visitors: a case study from Bavarian Forest National Park, Germany," European Journal of Forest Research, vol. 139, no. 3, pp. 431-442, 2020.

[110] J. Stachová, "Forests in the Czech public discourse," Journal of Landscape Ecology, vol. 11, no. 3, pp. 33-44, 2018.

[111] F. Pastorella, A. Avdagić, A. Čabaravdić, A. Mraković, M. Osmanović, and A. Paletto, "Tourists' perception of deadwood in mountain forests," Annals of Forest Research, vol. 59, no. 2, pp. 311-326, 2016.

[112] M. Köhl, R. Lasco, M. Cifuentes et al., "Changes in forest production, biomass and carbon: results from the 2015 UN FAO global forest resource assessment," Forest Ecology and Management, vol. 352, pp. 21-34.

[113] A. Paletto, F. Ferretti, I. De Meo, P. Cantiani, and M. Focacci, "Ecological and environmental role of deadwood in managed and unmanaged forests," Sustainable Forest Management-Current Research, pp. 219-238, 2012.

[114] M. Kortmann, J. Hurst, R. Brinkmann et al., "Beauty and the beast: how a bat utilizes forests shaped by outbreaks of an insect pest," Animal Conservation, vol. 21, no. 1, pp. 21-30, 2018.

[115] A. Y. Chang, Playing Nature: Ecology in Video Games, University of Minnesota Press, Minneapolis, MN, USA, 2019.

[116] E. Kituyi, "Climate change mitigation by schools in Kenya: policy options for scaling up sustainable fuel wood consumption and production," Renewable Energy Technology Assistance Programme, Policy Brief Series, 2008.

[117] F. W. Mugo, The Role of Woodfuel Conservation in Sustainable Supply of the Resource: The Case for Kenya, 2001.

[118] D. Ngui, J. Mutua, H. Osiolo, and E. Aligula, "Household energy demand in Kenya: an application of the linear approximate almost ideal demand system (LA-AIDS)," Energy Policy, vol. 39, no. 11, pp. 7084-7094, 2011.

[119] P. Wass, "Kenya's indigenous forests: status," Management and Conservation, vol. 12, no. 250, pp. 252-8317, 1995.

[120] N. Oduor and J. K. Githiomi, Forest Energy for Livelihoods, [Google Scholar], 2009.

[121] 2020 NBSAP Kenya National Biodiversity Strategy and Action Plan 2019-2030 (NBSAP), https://meas.nema.go.ke/ frontpage/download/Meas/Biodiversity/Plans-andStrategies/KENYA-NBSAPFINAL-DRAFT.pdf.

[122] Ministry of Environment and Forestry (MEF), Kenya: Updated Nationally Determined Contribution (NDC), 2020, https://www4.unfccc.int/sites/ndcstaging/ PublishedDocuments/Kenya\%20First/Kenya\%27s\%20First $\% 20 \% 20$ NDC $\% 20$.

[123] I. Mahiri and C. Howorth, "Twenty years of resolving the irresolvable: approaches to the fuelwood problem in Kenya," Land Degradation \& Development, vol. 12, no. 3, pp. 205215, 2001.

[124] Constitution of Kenya, "Land and environment chapter," 2010, http://kenyalaw.org:8181/exist/kenyalex/actview.xql? actid=Const 2010 .

[125] Forests Act, "2005 of the Laws of Kenya," 2020, http://www. kenyaforestservice.org/images/MMMB/forests\%20act\% 20no.7\%20of\%202005.pdf.

[126] Forests Act, "Forests Act (Cap. 385)," 2020, https://www. informea.org/en/legislation/forest-act-chapter-385\#: $\sim:$ text $=$ An\%20Act $\% 20$ of\%20Parliament $\% 20$ to,and $\% 20$ on $\%$ 20unalienated\%20Government\%20lands.

[127] M. Jonsell, J. Hansson, and L. Wedmo, "Diversity of saproxylic beetle species in logging residues in Sweden-comparisons between tree species and diameters," Biological Conservation, vol. 138, no. 1-2, pp. 89-99, 2007.

[128] P. Martikainen and J. Kouki, "Sampling the rarest: threatened beetles in boreal forest biodiversity inventories," Biodiversity and Conservation, vol. 12, no. 9, pp. 1815-1831, 2003. 